\title{
Prevalence and incidence of low back pain among runners: a systematic review
}

\author{
Filippo Maselli ${ }^{1,2^{*}}$ D, Lorenzo Storari ${ }^{1}$, Valerio Barbari ${ }^{1}$, Andrea Colombi ${ }^{1}$, Andrea Turolla ${ }^{3}$, Silvia Gianola ${ }^{4}$,
} Giacomo Rossettini ${ }^{1}$ and Marco Testa ${ }^{1}$

\begin{abstract}
Background: Running is one of the most popular sports worldwide. Despite low back pain (LBP) represents the most common musculoskeletal disorder in population and in sports, there is currently sparse evidence about prevalence, incidence and risk factors for LBP among runners. The aims of this systematic review were to investigate among runners: prevalence and incidence of LBP and specific risk factors for the onset of LBP.

Methods: A systematic review has been conducted according to the guidelines of the PRISMA statement. The research was conducted in the following databases from their inception to 31st of July 2019: PubMed; CINAHL; Google Scholar; Ovid; PsycINFO; PSYNDEX; Embase; SPORTDiscus; Scientific Electronic Library Online; Cochrane Library and Web of Science. The checklists of The Joanna Briggs Institute Critical Appraisal tools were used to investigate the risk of bias of the included studies.

Results: Nineteen studies were included and the interrater agreement for full-text selection was good ( $\mathrm{K}=0.78 ; 0.61-$ 0.80 IC 95\%). Overall, low values of prevalence (0.7-20.2\%) and incidence (0.3-22\%) of LBP among runners were reported. Most reported risk factors were: running for more than 6 years; body mass index > 24; higher physical height; not performing traditional aerobics activity weekly; restricted range of motion of hip flexion; difference between leglength; poor hamstrings and back flexibility.

Conclusions: Prevalence and incidence of LBP among runners are low compared to the others running related injuries and to general, or specific population of athletes. View the low level of incidence and prevalence of LBP, running could be interpreted as a protective factor against the onset of LBP.
\end{abstract}

Systematic review registration: PROSPERO CRD42018102001.

Keywords: Low Back pain, incidence, Prevalence, Running

\footnotetext{
* Correspondence: masellifilippo76@gmail.com

'Department of Neurosciences, Rehabilitation, Ophthalmology, Genetic and

Maternal Infantile Sciences (DINOGMI), University of Genova - Campus of

Savona, Savona, Italy

${ }^{2}$ Sovrintendenza Sanitaria Regionale Puglia INAIL, Bari, Italy

Full list of author information is available at the end of the article
}

(c) The Author(s). 2020 Open Access This article is licensed under a Creative Commons Attribution 4.0 International License, which permits use, sharing, adaptation, distribution and reproduction in any medium or format, as long as you give appropriate credit to the original author(s) and the source, provide a link to the Creative Commons licence, and indicate if changes were made. The images or other third party material in this article are included in the article's Creative Commons licence, unless indicated otherwise in a credit line to the material. If material is not included in the article's Creative Commons licence and your intended use is not permitted by statutory regulation or exceeds the permitted use, you will need to obtain permission directly from the copyright holder. To view a copy of this licence, visit http://creativecommons.org/licenses/by/4.0/ The Creative Commons Public Domain Dedication waiver (http://creativecommons.org/publicdomain/zero/1.0/) applies to the data made available in this article, unless otherwise stated in a credit line to the data. 


\section{Keypoints}

- Prevalence and incidence of LBP among runners seem basically low if compared with general population and other popular sports activities;

- Running could, cautiously, be considered a protective factor for the lumbar spine;

- Risk factors for the onset of LBP are generally physical impairments or training methods-related factors that could be partly modified and managed in clinical practice;

- Scarcity and methodological weakness of the available studies invite to conduct further research about actual prevalence and incidence as well as risk factors for LBP among runners;

- LBP may be better defined as Running Related Disorder instead of Running Related Injury.

\section{Background}

Running is one of the most practiced sports in the adult population worldwide, due to the sustainable cost of technical materials and its great beneficial impacts on health [1-11]. The benefits of running include weight control and prevention of chronic health disorders, such as the cardiovascular diseases, resulting in a general reduction of mortality risk [1-6]. The health benefits associated with running are well-documented, nevertheless the attention to lifestyle, diet, fitness and competitive athletics promoted by media in the last decade, have led to a drastic increase of the levels of physical activity and interest in both competitive and recreational running, even in subjects without an appropriate knowledge on training methodology [3-8]. Although evidence suggests that running is one of the most effective ways to achieve a good state of health and fitness [9], recent studies indicate that it also involves a relatively high risk of associated injury [10, 11]. Several authors have reported that $11-85 \%$ of recreational runners have at least one Running Related Injuries (RRIs) each year [10], resulting in a reduction or interruption of training in $30-90 \%$ of runners [11-13]. Acute RRIs are rare, almost $80 \%$ of RRIs are due to overuse, resulting from an imbalance between the resistance capacity of connective tissue and the biomechanical load of running $[14,15]$. The prevalence rate of RRIs among middle and long-distance runners has been reported to range between 19 and $92 \%$ [2, 16-20]. However, the discrepancies among studies limit the comparison of data due to the divergences in the type of runners analyzed, follow-up provided, study design, etiology and definition of RRIs [1, 2, 14-25]. In 2015, Yamato et al. [20] defined the RRIs as musculoskeletal pain or physical complaint of the lower limbs or of the back/trunk due to running, causing a total restriction or interruption of running for at least seven or more days and requiring therapeutic assistance [20]. Currently a definition of RRIs is not yet fully share [20], this is reflected in the difficulty of analyzing the studies about of RRIs [18]. RRIs therefore primarily affect joints of the lower limb, pelvis and lumbar spine [18, 25, 26], causing painful muscles, tendons and joints, often resulting in low back pain (LBP) [14-26]. It is frequent in clinical practice [27-33], that patients contact physical therapists for consultancy on LBP which represents a common complaint of athletes [27-33]. In the $90 \%$ of the cases, LBP is defined as non-specific, because the pathoanatomical musculoskeletal causes are not clearly identifiable [34]. LBP is one of the most common health problems in the world, that $80 \%$ of adults experience at some point in their life [35, 36]. Despite many published studies on the prevalence and incidence of LBP, there is not a clear consensus regarding its actual epidemiologic impact [37-40]. Indeed, some evidence reported a point prevalence estimate of LBP that ranged from 1 to $58 \%$ (mean 18.1\%) [39, 40]. One-year and lifetime's prevalence of LBP in the general worldwide population, ranged between $0.8-82.5 \%$ (mean $38,1 \%$ ) and $11-84 \%$ (mean 47,1\%), respectively [39,40]. Similarly, regarding a population of athletes [41], the percentage values of the prevalence of LBP remains wide, namely $1-94 \%$ in the lifetime (highest prevalence in rowing and crosscountry skiing) [41], and $18-65 \%$ for the point prevalence (lowest prevalence in basketball and highest prevalence in rowing) [41].

As seen in the general population, a big amount of athletes also experiences LBP [41-48]. Moreover, athletes of particular sport disciplines such as ski, rowing, golf, volleyball, track and fields, swimming or gymnastics are at greater risk of suffering from LBP than nonathletes population [33, 41, 43-48]. The incidence rates of low back pain in athletes have been reported up to $30 \%$ depending on the specific sport they are involved in [49]. However different authors describe also a great variability in prevalence rates, that have been reported in a range from $66 \%[50,51]$ to $88.5 \%$, respectively in young athletes and in elite athletes [52]. The incidence rate constitutes the frequency of new events of a medical disorder in the studied population considered at risk, calculated in a given period of time [53]. On the other hand, the prevalence proportion is the part (in percentage) of a defined population affected by a particular medical disorder at a given point in time, or over a specified period of time [53].

Despite several studies about the prevalence and incidence of LBP in general population and sports are retrievable [35-41], it seems that this topic has not been clearly investigated in the runners. Researches are mainly focused on RRIs in general but there are not Systematic Reviews (SRs) specifically addressing prevalence, 
incidence and risk factors for LBP in runners [11, 18]. Moreover, earlier literature of LBP has been addressed to a wide range of sports or athletes $[31,54]$ and no conclusive data were published peculiarly on the LBP among a specific population of runners. For this reason, the aims of this systematic review (SR) were to investigate among runners: 1) the prevalence and the incidence of LBP; and 2) specific risk factors for the onset of LBP.

\section{Methods}

\section{Study design and protocol}

The Preferred Reporting Items for Systematic Reviews and Meta-Analyses (PRISMA) protocol was used to design the present SR [55]. This SR has been registered in PROSPERO database (number CRD42018102001).

\section{Search strategy}

An electronic literature search was conducted in the following databases from their inception to 31st of July 2019: PubMed, CINAHL (EBSCO), Google Scholar, Ovid, PsycINFO, PSYNDEX, Embase, SPORTDiscus, Scientific Electronic Library Online (SciELO), Cochrane Library and Web of Science. Research strategies were conducted and designed depending on the specific settings of each database with the supervision of an expert librarian. The research strings were developed according to the PICO model of clinical question (participants, interventions, comparison and outcomes). Free-terms or synonyms (e.g. runners; risk factors; running-related injury), and when possible MeSH (Medical Subject Headings) terms (e.g. low back pain; prevalence; incidence) were used and combined with Boolean operators (AND, OR, NOT). Additionally, a manual research has been conducted through the bibliographies of all the assessed studies to obtain an integrative cross-references full-text selection. A dedicated search strategy was prepared for each database. We have reported the full search strategy for PubMed in Additional file 1.

\section{Eligibility criteria}

All studies were conducted on runners without age limitation. We included any type of study design aiming to investigate prevalence, incidence or risk factors for LBP as RRIs (e.g., cross-sectional, case-control, prospective and retrospective cohort studies). Moreover, single cohort designs were also considered. Runners of any kind of experience or mileage were included, whereas sprinters and track and field athletes were not considered. We defined as RRI any occurrence severe enough to avoid or even restrict the running activity for at least $24 \mathrm{~h}$. We selected studies reporting at least one anatomical area included in LBP definition such as area located below the margin of the 12th rib and above inferior gluteal fold (included: pelvis/pelvis crest, sacrum and gluteus/buttock) [56] and the pathoanatomical cause of the pain cannot be determined [57]. We selected studies published in English or Italian language without limits of date of publication. Descriptive observational designs, such as case report and case series, and any study, which did not meet the inclusion criteria, were excluded.

\section{Study selection}

The selection and data collection process were done by two reviewers (FM and $\mathrm{AC}$ ) under the supervision of a third author (MT). The whole records were screened by the management software for systematic reviews "Rayyan" (https://rayyan.qcri.org), while references were managed by the "Mendeley" software (https://www.mendeley.com). After the removal of the duplicates, titles and abstracts were screened. Then, full-texts of the identified studies were obtained for further assessment and analyzed independently according to the eligibility criteria by two reviewers (FM and $\mathrm{AC}$ ). Where appropriate, authors were contacted in order to obtain the full-text.

\section{Data collection}

For each article, the following data was extracted: study design; author, year of publication; the number and characteristics of participants/populations; international definition and/or any diagnostic criteria for LBP; analysis of the variables and the outcome of the studies; study settings/country (e.g., marathon, half-marathon, survey, lab analysis); prevalence and incidence rates; intervention and results; follow-up or study duration; theoretical perspectives on potential risk factors on the onset of LBP: reported risk factors; outcomes and measurements to associate the risks associated with LBP (e.g., relative risk, odds ratio, etc.).

\section{Quality assessment}

The Risk of Bias (RoB) of the included studies is analyzed using the Joanna Briggs Institute Critical Appraisal tools [58] according to the specific study design (e.g., prevalence data, cross-sectional studies, case-control studies, prospective studies). In addition, as prevalence data may be sourced from several numbers of study designs, a critical appraisal checklist specifically for prevalence studies were used. Two independent researchers (FM, LS) evaluated the RoB. The score of RoB was not adopted as criteria to include/exclude studies in this review.

\section{Agreement}

Cohen's Kappa (K) was used to assess the interrater agreement between the two authors (FM, AC) for fulltext selection ( $\mathrm{K}=0.78 ; 0.61-0.80$ IC 95\%). Cohens' $\mathrm{K}$ was interpreted according to Altman's definition: $\mathrm{k}<$ 


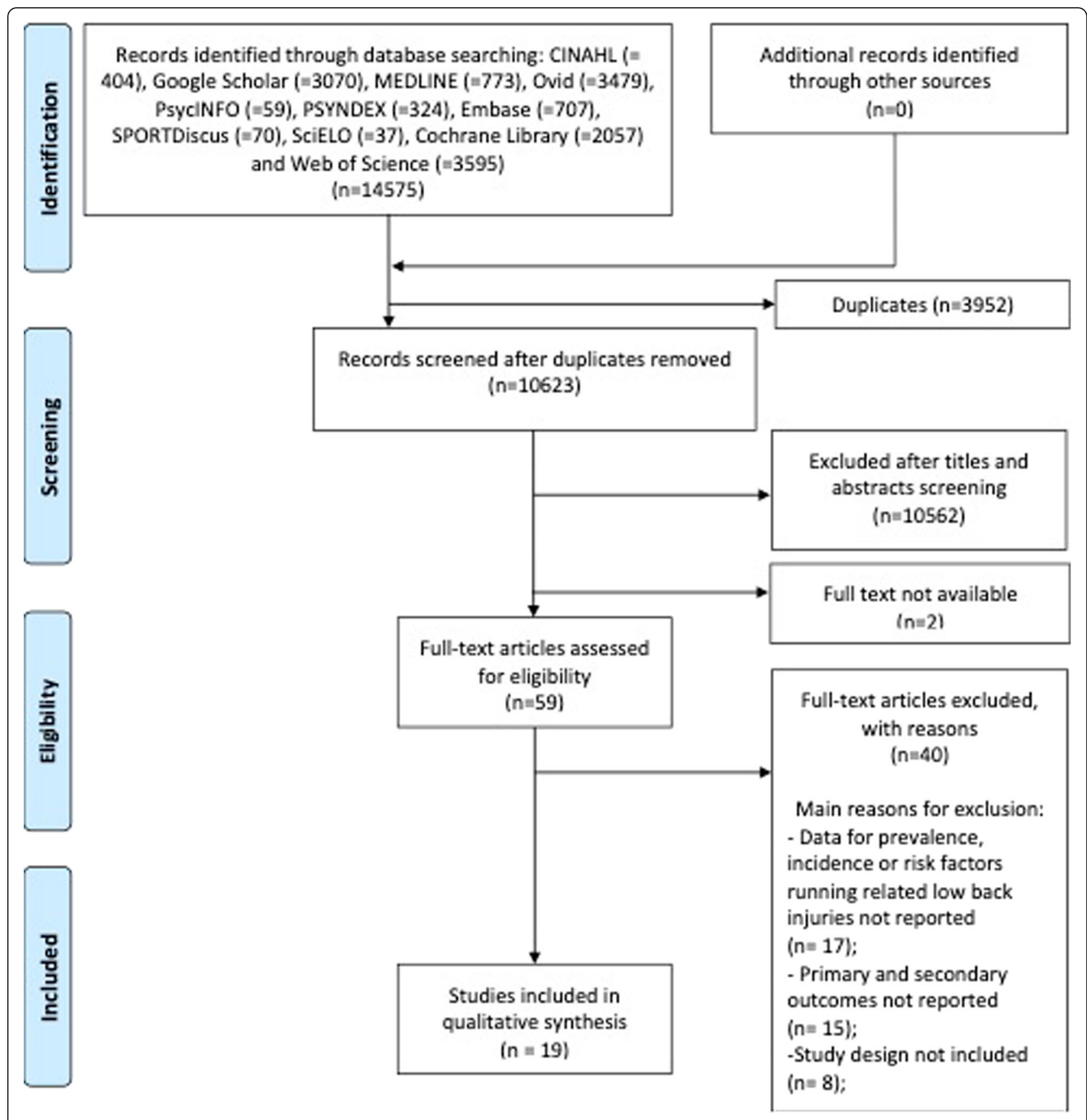

Fig. 1 PRISMA 2009 flow diagram

0.20 poor, $0.20<\mathrm{k}<0.40$ fair, $0.41<\mathrm{k}<0.60$ moderate, $0.61<\mathrm{k}<0.80$ good, $0.81<\mathrm{k}<1.00$ excellent [59].

\section{Data analysis}

We reported the data related to the prevalence, incidence and risk factors for LBP from each study. When needed, we estimated data on prevalence, incidence and risk factors using available data of the included studies. We reported the prevalence and incidence percentage in table form.

\section{Results}

\section{Study selection process}

Electronic database searches and the identification of additional references yielded 14,575 records, including 3952 duplicates that were removed. After screening titles and abstracts, 10,564 (including 2 full-text not available) records were excluded. Then, 59 potentially relevant studies were considered eligible for full-text assessment, resulting in 19 included studies in this SR for quality assessment, data extraction and analysis. The selection 
Table 1 Studies Exclusion

\begin{tabular}{|c|c|}
\hline First Author, Year & Journal, Title \\
\hline Aggrawal ND, 1979 & $\begin{array}{l}\text { Br J Sports Med } \\
\text { A Study of changes in the spine in weight-lifters and other } \\
\text { athletes }\end{array}$ \\
\hline $\begin{array}{l}\text { Bertelsen ML, } 2017 \\
\text { [24] }\end{array}$ & $\begin{array}{l}\text { Scand J Med Sci Sports } \\
\text { A framework for the etiology of running-related injuries }\end{array}$ \\
\hline Brill PA, 1995 & $\begin{array}{l}\text { Sports Med } \\
\text { The influence of running patterns on running } \\
\text { injuries. }\end{array}$ \\
\hline Buist I, 2010 & $\begin{array}{l}\text { Am J Sports Med } \\
\text { Predictors of running-related injuries in novice runners en- } \\
\text { rolled in } \\
\text { a systematic training program: a prospective cohort study }\end{array}$ \\
\hline
\end{tabular}

Burrows M, $2003 \quad$ Br J Sports Med

Physiological factors associated with low bone mineral density in female endurance runners

Cai C, 2015

Cole AJ, 1995

Damsted C, 2019

Fokkema T, 2018

Franke TPC, 2019 [5]

Fredericson M, 2007

Garbutt G, 1990 [60]

J Orthop Sports Phys Ther

Low Back and Lower Limb Muscle Performance in Male and Female Recreational Runners with Chronic Low Back Pain

J Back Musculoskelet Rehabil

Spine injuries in runners: A functional approach

J Orthop Sports Phys Ther

Preparing for half-marathon: The association between changes in weekly running distance and running-related injuries - does it matter how the running is scheduled?

J Sci Med Sport

Prognosis and

prognostic factors of running-related injuries in novice run-

ners: a

prospective cohort study

Orthop Sports Phys Ther

Running Themselves Into the Ground? Incidence, Prevalence, and Impact of Injury and Illness in Runners Preparing for a Half or Full Marathon

\section{Sports Med}

Epidemiology and aetiology of marathon running injuries

Med Sci Sports Exerc

Running speed and spinal shrinkage in runners with and without low back pain

Hamill J, 2009

Res Sports Med

Lower extremity joint stiffness in runners with low back pain

Hespanhol Junior LC, 2016

Jacobs S, 1986

Kemler E, 2018 [12] Phys Sportsmed

Scand J Med Sci Sports

Health and economic burden of running-related injuries in runners training for an event: a prospective cohort study

Am J Sports Med

Injuries to runners: a study of entrants to a 10,000-m race.

The relationship between the use of running applications and running-related injuries

Kluitenberg B, 2013 BMC Public Health

The NLstart2run study: health effects of a running promotion program in novice runners, design of a prospective cohort study

Kluitenberg B, 2016 J Sci Med Sport
Reasons For Exclusion

Data for prevalence, incidence or risk factors running related

low back injuries are not reported

This study evaluates the spine complaints in weight-lifters and track and field athletes

Study design is not included

Study design is not included

Primary and secondary outcomes are not evaluated

Primary and secondary outcomes are not evaluated This study analyzes the BMD (bone mass index) of several body segments after physical exercises

Primary and secondary outcomes not evaluated

This study evaluates some physical test such as muscular strength and length

Data for prevalence, incidence or risk factors running related low back injuries are not reported

Study design is not relevant

Primary and secondary outcomes are not evaluated.

This study evaluates only running-related injuries localized in the lower limb

Data for prevalence, incidence or risk factors running related low back injuries are not reported

Data for prevalence, incidence or risk factors running related low back injuries are not reported

This study grouped the data for head, spine and trunk

Study design is not included

Data for prevalence, incidence or risk factors running related low back injuries are not reported

This study analyzes the spinal shrinkage in runners. The authors consider LBP as an independent of the shrinkage induced by running

Primary and secondary outcomes are not evaluated.

This study evaluates the joint stiffness of hip, knee and ankle in runners with current $L B P$, resolved $L B P$ and controls

Data for prevalence, incidence or risk factors running related low back injuries are not reported

Primary and secondary outcomes are not evaluated

Data for prevalence, incidence or risk factors running related low back injuries are not reported

Study design is not included

Primary and secondary outcomes are not evaluated. 
Table 1 Studies Exclusion (Continued)

\begin{tabular}{ll}
\hline First Author, Year & Journal, Title \\
\hline & The NLstart2run study: training-related factors associated with \\
& running-related injuries in novice runners \\
Lee SP, 2018 & $\begin{array}{l}\text { Phys Ther Sport } \\
\text { Adaptations of lumbar biomechanics after four weeks of } \\
\text { running training with minimalist footwear and technique } \\
\text { guidance: Implications for running-related lower back pain }\end{array}$
\end{tabular}

Lewis G, 2000

Linton L, 2018

Lopes AD, 2011

Nielsen RO, 2019

Classifying running-related injuries based upon etiology, with emphasis on volume and pace

Noormohammadpour Eur Spine J

P, 2015

Ogon M, 1999

Oliveira RR, 2017

Preece SJ, 2016

Sado N, 2017

Schafer WE⿺ 1985

Scheer BV, 2011 [62]

Seay JF, 2014

ISMJThe etiology and clinical features of low back pain in distance runners: a review

J Sci Med Sport

Running with injury: a study of UK novice and

recreational runners and factors associated with running related injury

Musculoskeletal pain is

prevalent among recreational runners who are about to compete: an observational study of 1049 runners

BMJ Open of runningrelated injuries: rationale and design of an 18 to different sport activities

Foot Ankle Int

Does arch height affect impact loading at the lower back level in running?

Int J Sports Phys Ther

There are no biomechanical differences between runners classified by the functional movement screen

\section{Gait Posture}

How do elite endurance runners alter movements of the spine and pelvis as running speed increases?

\section{Sports Biomech} in maximal sprint running

Stress Health

Life changes, stress, injury and illness in adult runners

\section{Clin J Sport Med} during a 219-km, 5-day ultramarathon stage race

\section{ur sport Sci}

Nielsen RO, 2013 [61] Int J Phys Ther

The Garmin-RUNSAFE Running Health Study on the aetiology month prospective cohort study including runners worldwide

Low back pain status of female university students in relation

The three-dimensional kinetic behaviour of the pelvic rotation

Al Andalus Ultra Trail: an observation of medical interventions

Trunk bend and twist coordination is affected by low back pain status during running

Res Sports Med

Validity of injury self-reports by novice runners: comparison with reports by sports medicine physicians
Int J Sport Health Sci
Reasons For Exclusion

This study analyzes the risk factors for running-related injury without referring to specific anatomical sites for each participant

Primary and secondary outcomes are not evaluated The authors report only that incorporating minimalist footwear and technique coaching into a runners' training may induce changes in lumbar biomechanics associated with reduced risk of running related LBP, without any statistical analysis

Study design is not relevant

Data for prevalence, incidence or risk factors running related low back injuries are not reported

Data for prevalence, incidence or risk factors running related low back injuries are not reported

This study evaluated the general spine complaints

Study design is not included

Study design is not included

Data for prevalence, incidence or risk factors running related low back injuries are not reported

This study evaluates the LBP status in 9 sports, but not among runner

Primary and secondary outcomes are not evaluated

Primary and secondary outcomes are not evaluated This study evaluates the timing of TrA (transversus abdominis muscle) activation and the sit and reach test such as possible factors for LBP development

Primary and secondary outcomes are not evaluated This study analyzes some cinematics parameters of the spine and pelvis without any consideration for LBP

Primary and secondary outcomes are not evaluated This study analyzes the lumbosacral cinematic to improve the sprint performance in running

Data for prevalence, incidence or risk factors running related low back injuries are not reported

Data for prevalence, incidence or risk factors running related low back injuries are not reported

Data for prevalence, incidence or risk factors running related low back injuries are not reported

This study analyzes the differences in trunk sagittal kinematics between 3 groups of runners, with current LBP, resolved LBP or controls

Data for prevalence, incidence or risk factors running related low back injuries are not reported

This study examines the criterion validity of self-reported running related injuries, compared to an injury consultation by a sport medicine physician

Primary and secondary outcomes are not evaluated 
Table 1 Studies Exclusion (Continued)

\begin{tabular}{|c|c|c|}
\hline First Author, Year & Journal, Title & Reasons For Exclusion \\
\hline & $\begin{array}{l}\text { The Relationship between 30-m Sprint Running Time and } \\
\text { Muscle Cross-sectional Areas of the Psoas Major and Lower } \\
\text { Limb Muscles in Male College Short and Middle Distance } \\
\text { Runners }\end{array}$ & \\
\hline Tam N, 2018 & $\begin{array}{l}\text { J Sports Sci } \\
\text { Bone health in elite Kenyan runners }\end{array}$ & Primary and secondary outcomes are not evaluated \\
\hline Tauton JE, 2002 & $\begin{array}{l}\text { Br J Sports Med } \\
\text { A retrospective case-control analysis of } 2002 \text { running injuries }\end{array}$ & $\begin{array}{l}\text { Data for prevalence, incidence or risk factors running related } \\
\text { low back injuries are not reported } \\
\text { This study evaluates the running-related injury in athletes of } \\
\text { different sports such as cycling, swimming, weight-lifting, etc. } \\
\text { who referred to had an injury during running activity }\end{array}$ \\
\hline Villavicencio AT, 2006 & $\begin{array}{l}\text { Neurosurg Focus } \\
\text { Back and neck pain in triathletes }\end{array}$ & $\begin{array}{l}\text { Data for prevalence, incidence or risk factors running related } \\
\text { low back injuries are not reported } \\
\text { The study population is triathlon athletes }\end{array}$ \\
\hline Wen DY, 2007 & $\begin{array}{l}\text { Curr Sports Med Rep } \\
\text { Risk Factors for Overuse Injuries } \\
\text { in Runners }\end{array}$ & Study design is not included \\
\hline Winter SC, 2018 & $\begin{array}{l}\text { J Phy Fit Treatment \& Sports } \\
\text { Centre of Mass Acceleration-Derived Variables Detects Differ- } \\
\text { ences between Runners of Different Abilities and Fatigue- } \\
\text { Related Changes during a Long Distance Over ground Run }\end{array}$ & $\begin{array}{l}\text { Primary and secondary outcomes are not evaluated. } \\
\text { This study evaluates the differences in running movements } \\
\text { using a wireless accelerometers }\end{array}$ \\
\hline Winter SC, 2019 & $\begin{array}{l}\text { Res Sports Med } \\
\text { Overuse injuries in runners of different abilities-a one-year } \\
\text { prospective study. }\end{array}$ & $\begin{array}{l}\text { Data for prevalence, incidence or risk factors running related } \\
\text { low back injuries are not reported } \\
\text { This study provides the total amount of injuries for the } \\
\text { groups of running level. The single anatomical site of injury } \\
\text { for each runner was not included }\end{array}$ \\
\hline
\end{tabular}

process is described in Fig. 1 according to the PRISMA Statement [55]. Reasons for exclusions are reported in Table 1.

\section{Characteristics of the included studies}

The 19 included studies were: cross-sectional $(n=6)$ [63-68]; retrospective $(n=3)$ [69-71]; and prospective $(n=10)$ [72-81]. They were all published in English, starting from 1981 [69] to 2019 [66, 80]. Overall, followups or time duration of these studies ranged from 6 weeks [76] to 2 years [79], while sample sizes varied from a minimum of 4059 to a maximum of 4380 participants [66]. The characteristics of included studies are reported in Table 2.

\section{Risk of Bias of the included studies}

Details of the RoB of the included studies are presented in Tables 3, 4, 5 and 6. Most items of all RoB assessment tools used for the quality assessment were rated as low risk. For all the studies addressing prevalence data regardless of the study design $[63-65,67,68,70,81]$, the items rated as unclear $\mathrm{RoB}$ were related to the sampling methods in 3 studies $[63,65,70]$, while in one study the items rated as high risk [68]. More in depth in one study [68], another two items were rated as high risk, one regarding the reliability of the condition measurement and one regarding the validity of identification of the condition. For cross-sectional studies, the majority of studies had low and, less commonly, unclear RoB [63-68]. However, among them, in the study of Marti et al. [68], the item related to the criteria for inclusion was rated as high risk, likewise the item about the reliability of the condition measurement in the study of Chang et al. [67]. For retrospective studies [69-71] there was a low RoB across all the studies, apart from comparability of groups, matching of cases and controls, adoption of the same criteria for identification of case and controls and methods to measure the exposure in 3 studies [69-71], which were all rated as not applicable. Finally, for prospective studies [72-81], in 6 studies [71, 73-76, 79] items related to the similarity/recruitment of groups, methods of exposure were rated as not applicable. Also were judged as not applicable the items related to the time of follow-up and loss to follow-up in the study of Back et al. [72]. Moreover, in 3 studies [72, 74, 78] the item about strategies to address incomplete follow up was evaluated as not applicable, whereas the remaining items were commonly judged as low RoB.

\section{Summary of findings}

Results about prevalence and incidence are reported in Table 7.

\section{Prevalence of LBP}

Eight $[63-68,70,81]$ of the 19 included studies addressed prevalence of LBP among runners. Six were 


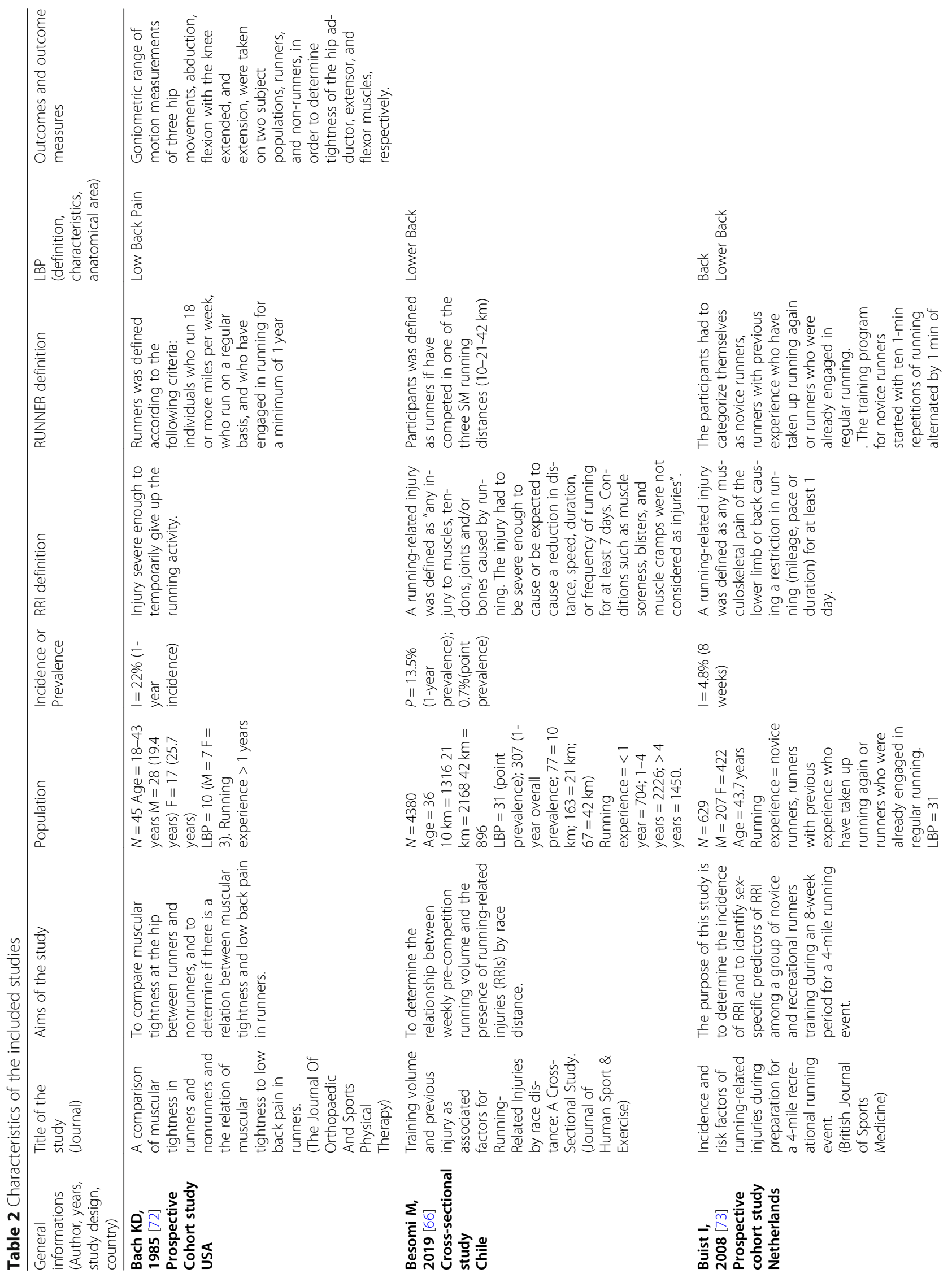




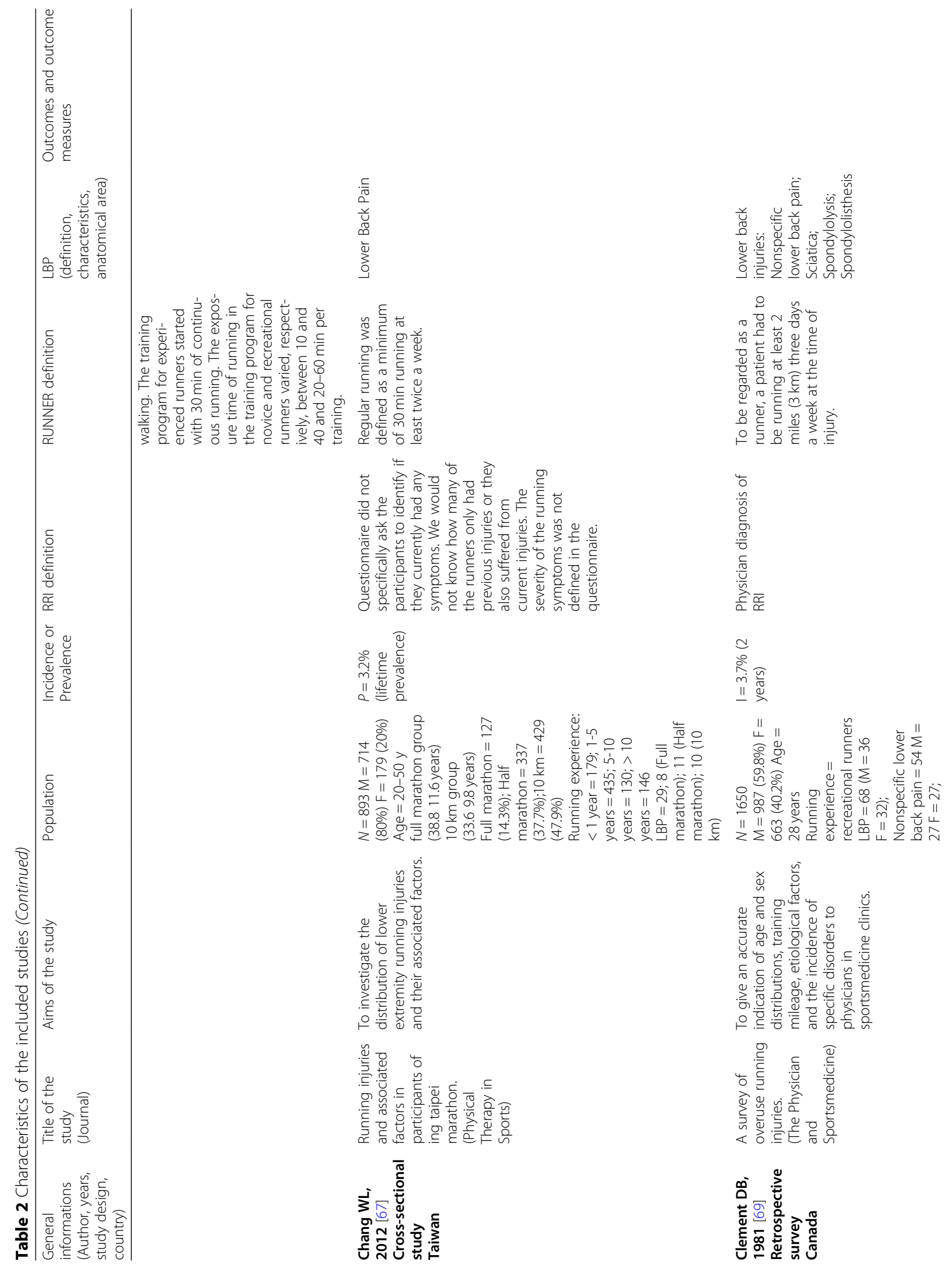




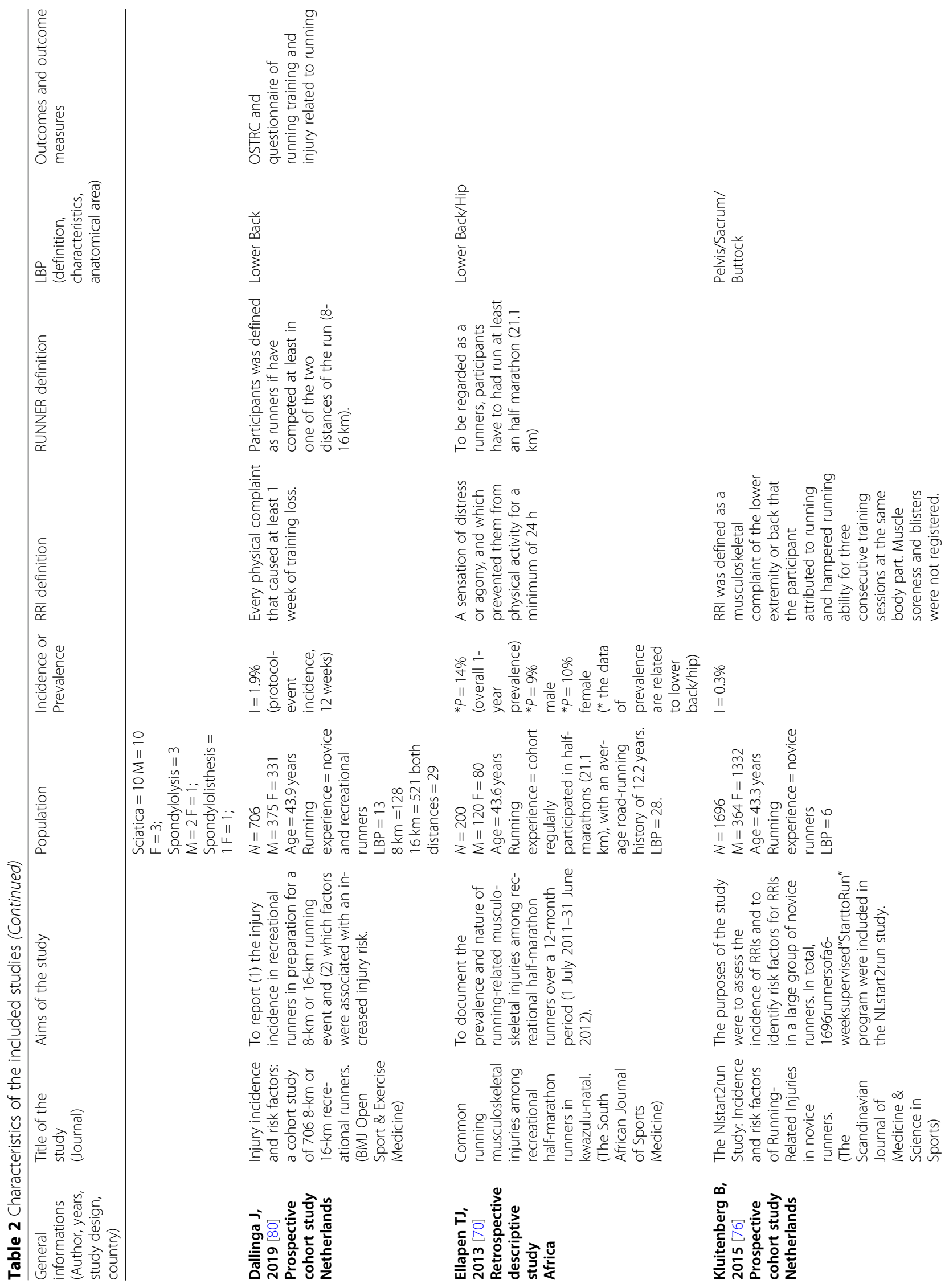




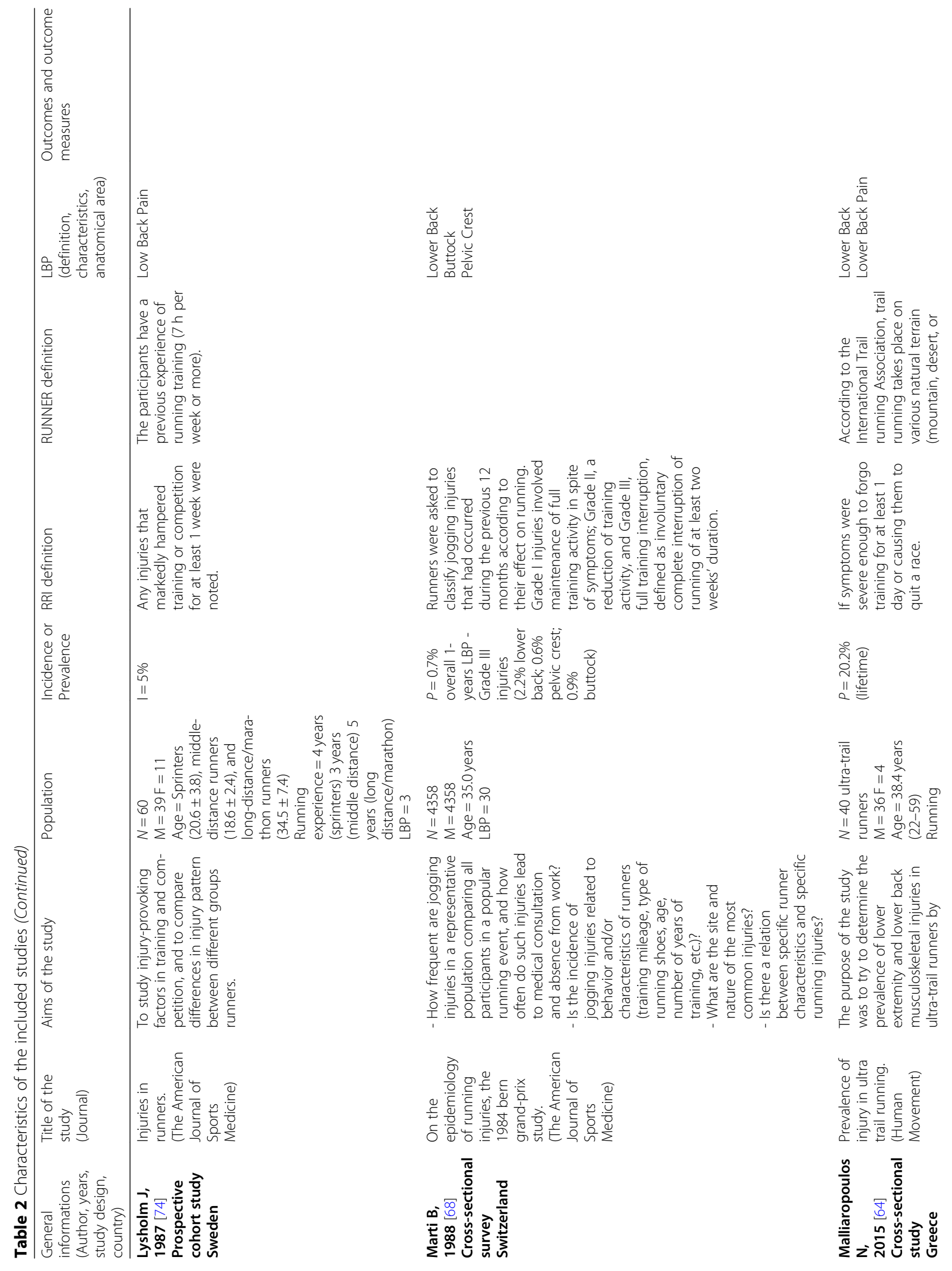




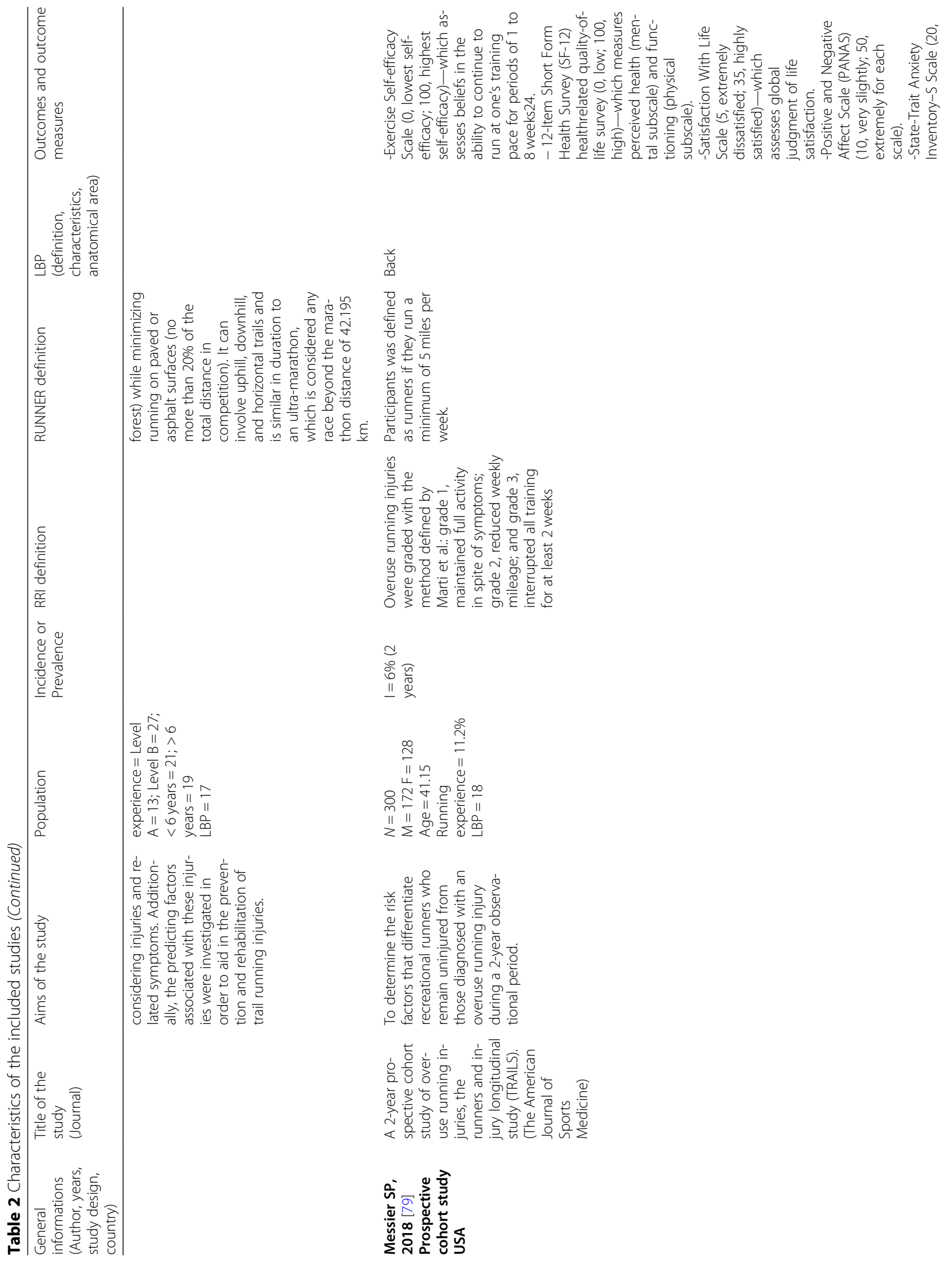




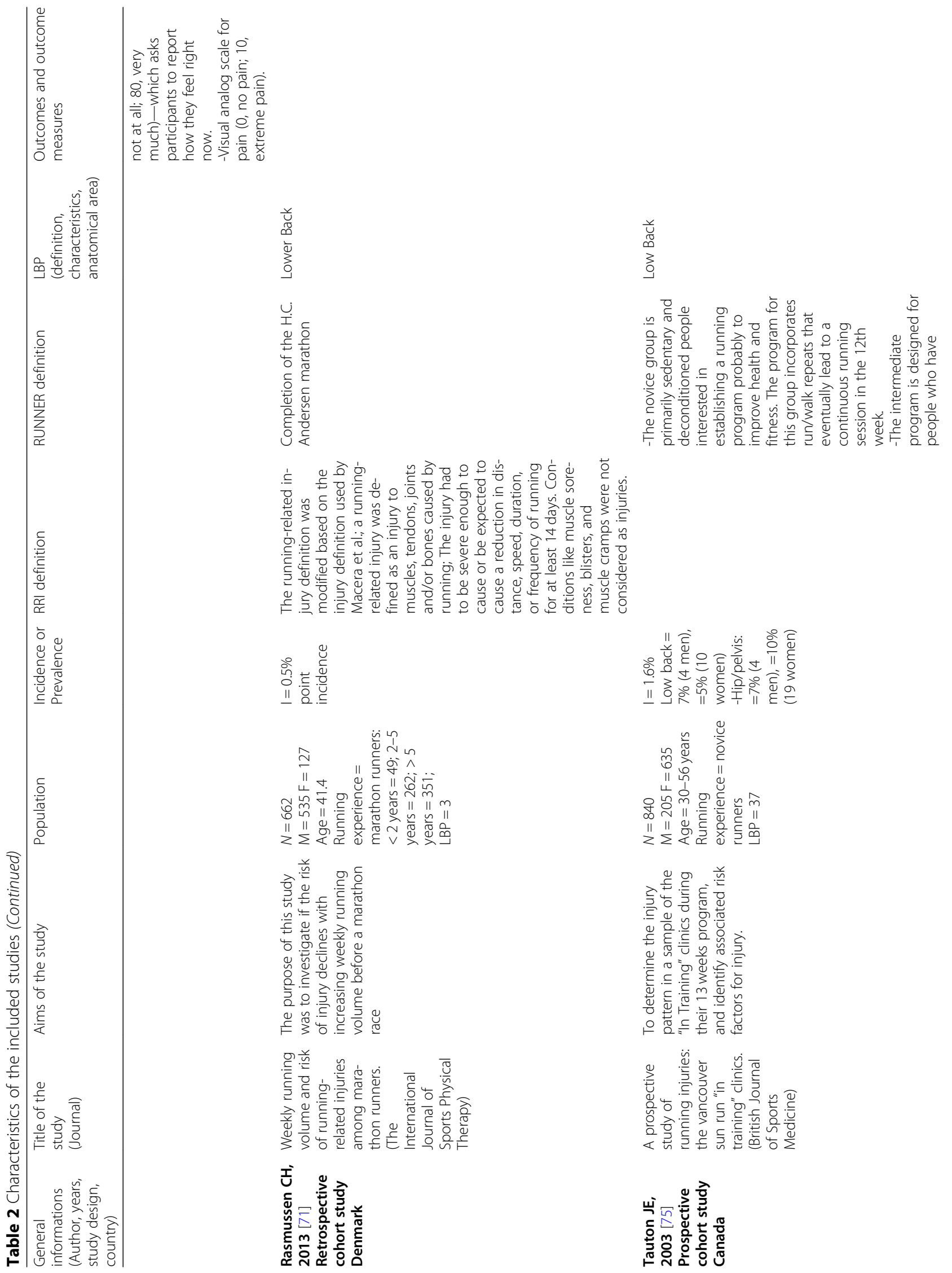




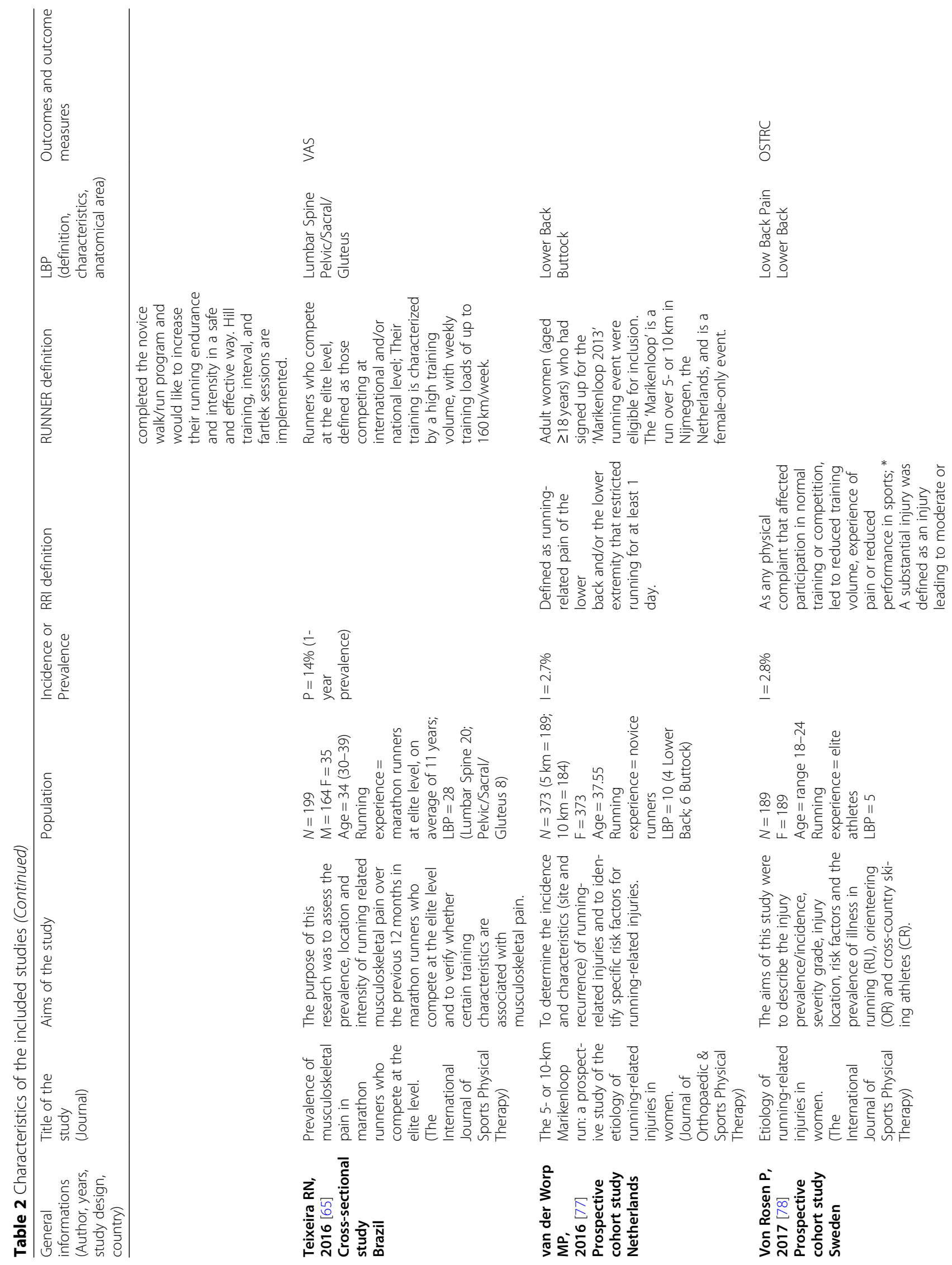




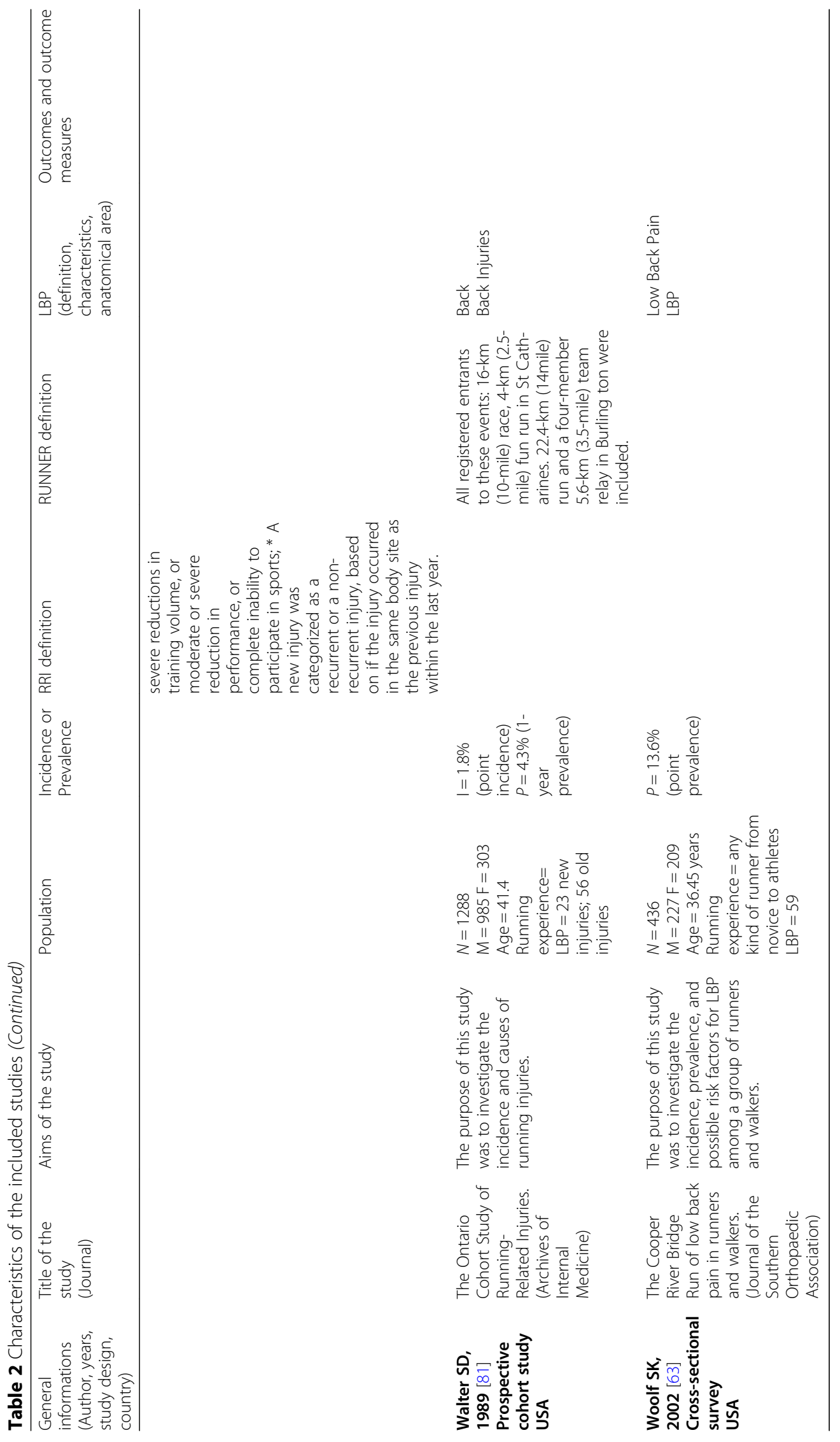


Table 3 Case Control Critical Appraisal

\begin{tabular}{|c|c|c|c|}
\hline & Clement DB. 1981 [69] & Ellapen TJ. 2013 [70] & Rasmussen CH. 2013 [71] \\
\hline $\begin{array}{l}\text { Were the groups comparable other than the presence of disease in cases } \\
\text { or the absence of disease in controls? }\end{array}$ & Not applicable & Not applicable & Not applicable \\
\hline Were cases and controls matched appropriately? & Not applicable & Not applicable & Not applicable \\
\hline Were the same criteria used for identification of cases and controls? & Not applicable & Not applicable & Not applicable \\
\hline Was exposure measured in a standard, valid and reliable way? & Unclear & Yes & Yes \\
\hline Was exposure measured in the same way for cases and controls? & Not applicable & Not applicable & Not applicable \\
\hline Were confounding factors identified? & Yes & Yes & Yes \\
\hline Were strategies to deal with confounding factors stated? & Yes & Yes & Yes \\
\hline $\begin{array}{l}\text { Were outcomes assessed in a standard, valid and reliable way for cases } \\
\text { and controls? }\end{array}$ & Yes & Yes & Yes \\
\hline Was the exposure period of interest long enough to be meaningful? & Yes & Yes & Yes \\
\hline Was appropriate statistical analysis used? & Unclear & Yes & Yes \\
\hline
\end{tabular}

Table 4 Cohort Critical appraisal

\begin{tabular}{|c|c|c|c|c|c|c|c|c|c|c|}
\hline & $\begin{array}{l}\text { Dallinga } \\
\text { J. } 2019 \\
{[80]}\end{array}$ & $\begin{array}{l}\text { Bach DK. } \\
1985[72]\end{array}$ & $\begin{array}{l}\text { Buist I. } \\
2008 \text { [73] }\end{array}$ & $\begin{array}{l}\text { Lysholm } \\
\text { J. } 1987 \\
\text { [74] }\end{array}$ & $\begin{array}{l}\text { Tauton JE. } \\
2003[75]\end{array}$ & $\begin{array}{l}\text { Van der } \\
\text { Worp MP. } \\
2016 \text { [77] }\end{array}$ & $\begin{array}{l}\text { Messier } \\
\text { SP. } \\
2018 \\
{[79]}\end{array}$ & $\begin{array}{l}\text { Kluitenberg } \\
\text { B. } 2015[76]\end{array}$ & $\begin{array}{l}\text { Von } \\
\text { Rosen P. } \\
2017 \text { [78] }\end{array}$ & $\begin{array}{l}\text { Walter } \\
\text { SD. } 1989 \\
\text { [81] }\end{array}$ \\
\hline $\begin{array}{l}\text { Were the two groups similar } \\
\text { and recruited from the same } \\
\text { population? }\end{array}$ & Yes & Yes & $\begin{array}{l}\text { Not } \\
\text { applicable }\end{array}$ & Yes & $\begin{array}{l}\text { Not } \\
\text { applicable }\end{array}$ & $\begin{array}{l}\text { Not } \\
\text { applicable }\end{array}$ & Yes & $\begin{array}{l}\text { Not } \\
\text { applicable }\end{array}$ & $\begin{array}{l}\text { Not } \\
\text { applicable }\end{array}$ & $\begin{array}{l}\text { Not } \\
\text { applicable }\end{array}$ \\
\hline $\begin{array}{l}\text { Were the exposures measured } \\
\text { similarly to assign people to } \\
\text { both exposed and unexposed } \\
\text { groups? }\end{array}$ & Yes & Yes & $\begin{array}{l}\text { Not } \\
\text { applicable }\end{array}$ & Yes & $\begin{array}{l}\text { Not } \\
\text { applicable }\end{array}$ & $\begin{array}{l}\text { Not } \\
\text { applicable }\end{array}$ & Yes & $\begin{array}{l}\text { Not } \\
\text { applicable }\end{array}$ & $\begin{array}{l}\text { Not } \\
\text { applicable }\end{array}$ & $\begin{array}{l}\text { Not } \\
\text { applicable }\end{array}$ \\
\hline $\begin{array}{l}\text { Was the exposure measured in } \\
\text { a valid and reliable way? }\end{array}$ & Yes & Yes & Yes & Yes & Unclear & Unclear & Yes & Unclear & Unclear & Unclear \\
\hline $\begin{array}{l}\text { Were confounding factors } \\
\text { identified? }\end{array}$ & Yes & Unclear & Yes & Unclear & Yes & Yes & Yes & Yes & Yes & Yes \\
\hline $\begin{array}{l}\text { Were strategies to deal with } \\
\text { confounding factors stated? }\end{array}$ & Unclear & Unclear & Yes & Unclear & Yes & Yes & Yes & Yes & Yes & Yes \\
\hline $\begin{array}{l}\text { Were the groups/participants } \\
\text { free of the outcome at the } \\
\text { start of the study (or at the } \\
\text { moment of exposure)? }\end{array}$ & Unclear & Yes & Unclear & Yes & Unclear & Unclear & Yes & Yes & Unclear & Unclear \\
\hline $\begin{array}{l}\text { Were the outcomes measured } \\
\text { in a valid and reliable way? }\end{array}$ & Yes & Yes & Yes & Unclear & Yes & Yes & Yes & Yes & Yes & Yes \\
\hline $\begin{array}{l}\text { Was the follow up time } \\
\text { reported and sufficient to be } \\
\text { long enough for outcomes to } \\
\text { occur? }\end{array}$ & Yes & $\begin{array}{l}\text { Not } \\
\text { applicable }\end{array}$ & Unclear & Yes & Yes & Yes & Yes & Unclear & Yes & Yes \\
\hline $\begin{array}{l}\text { Was follow up complete, and if } \\
\text { not, were the reasons to loss to } \\
\text { follow up described and } \\
\text { explored? }\end{array}$ & Yes & $\begin{array}{l}\text { Not } \\
\text { applicable }\end{array}$ & Yes & Yes & Yes & Yes & Yes & Yes & Yes & Yes \\
\hline $\begin{array}{l}\text { Were strategies to address } \\
\text { incomplete follow up utilized? }\end{array}$ & Yes & $\begin{array}{l}\text { Not } \\
\text { applicable }\end{array}$ & Yes & $\begin{array}{l}\text { Not } \\
\text { applicable }\end{array}$ & Unclear & No & Yes & Yes & $\begin{array}{l}\text { Not } \\
\text { applicable }\end{array}$ & Yes \\
\hline $\begin{array}{l}\text { Was appropriate statistical } \\
\text { analysis used? }\end{array}$ & Yes & Yes & Yes & Yes & Yes & Yes & Yes & Yes & Yes & Yes \\
\hline
\end{tabular}


Table 5 Cross Sectional Critical Appraisal

\begin{tabular}{|c|c|c|c|c|c|c|}
\hline & $\begin{array}{l}\text { Chang WL. } \\
2012[67]\end{array}$ & $\begin{array}{l}\text { Malliaropoulos N. } \\
2015 \text { [64] }\end{array}$ & $\begin{array}{l}\text { Marti B. } \\
1988[68]\end{array}$ & $\begin{array}{l}\text { Woolf S. } \\
2002[63]\end{array}$ & $\begin{array}{l}\text { Teixeira RN. } \\
2016[65]\end{array}$ & $\begin{array}{l}\text { Besomi M., } \\
2019[66]\end{array}$ \\
\hline $\begin{array}{l}\text { Were the criteria for inclusion in the sample clearly } \\
\text { defined? }\end{array}$ & Yes & Yes & No & No & Yes & Yes \\
\hline $\begin{array}{l}\text { Were the study subjects and the setting described } \\
\text { in detail? }\end{array}$ & Yes & Yes & Yes & Yes & Yes & Yes \\
\hline $\begin{array}{l}\text { Was the exposure measured in a valid and reliable } \\
\text { way? }\end{array}$ & Yes & Yes & Yes & Yes & Yes & Yes \\
\hline $\begin{array}{l}\text { Were objective, standard criteria used for } \\
\text { measurement of the condition? }\end{array}$ & No & Yes & Yes & Yes & Yes & Yes \\
\hline Were confounding factors identified? & Unclear & Yes & Yes & Yes & Yes & Yes \\
\hline $\begin{array}{l}\text { Were strategies to deal with confounding factors } \\
\text { stated? }\end{array}$ & Unclear & Yes & Yes & Unclear & Yes & Yes \\
\hline $\begin{array}{l}\text { Were the outcomes measured in a valid and } \\
\text { reliable way? }\end{array}$ & Unclear & Yes & Yes & Unclear & Yes & Yes \\
\hline Was appropriate statistical analysis used? & Yes & Yes & Yes & Yes & Yes & Yes \\
\hline
\end{tabular}

cross-sectional studies [63-68], one was a retrospective study [70] and one was a prospective study [81]. The range of point prevalence ranged from a minimum of 0 , $7 \%$ [66] at a maximum of $13.6 \%$ [63] and lifetime prevalence ranged from a minimum of $3.2 \%$ [67] a maximum of $20.2 \%$ [64]. Point prevalence values, 13.6 and $0.7 \%$ respectively, were reported in two studies [58, 64]. Five studies reported values of 1-year prevalence $[65,66,68$, $70,81]$, ranged from $14 \%[65,70]$ to $0.7 \%$ [68], and those about lifetime prevalence were two [63, 64], 3.2 and $20.2 \%$ respectively. Only 1 study [66] addressed data for point and 1-year prevalence, with values of 0.7 and $13.5 \%$ respectively [66]. Also in the cross-sectional survey study of Woolf et al. [63], the point prevalence of
LBP in runners was reported, and it was equal to $13.6 \%$. The study of Marti et al. [68] reported a 1-year prevalence of LBP of $0.7 \%$, but this value was calculated in a sample of all male runners, and it was referred only to the Grade III injuries (defined as full training involuntary interruption of running for at least 2 weeks duration). In the cross-sectional study of Teixeira et al. [65] 1-year prevalence of LBP (including pain in the lumbar spine and pain in pelvic/sacral/gluteus regions) among elite marathon runners was $14 \%$. In the retrospective descriptive study of Ellapen et al. [70] the 1-year prevalence of lower back (including hip) among recreational halfmarathon runners was $14 \%$ (mean value; $13 \%$ for men, $15 \%$ for women). In the only prospective cohort study,

Table 6 Prevalence Studies Critical Appraisal

\begin{tabular}{|c|c|c|c|c|c|c|c|c|}
\hline & $\begin{array}{l}\text { Chang WL. } \\
2012[67]\end{array}$ & $\begin{array}{l}\text { Marti B. } \\
1988[68]\end{array}$ & $\begin{array}{l}\text { Ellapen } \\
\text { TJ. } \\
2013 \\
{[70]}\end{array}$ & $\begin{array}{l}\text { Malliaropoulos } \\
\text { N. } \\
2015 \text { [64] }\end{array}$ & $\begin{array}{l}\text { Walter } \\
\text { SD. } \\
1989 \\
{[81]}\end{array}$ & $\begin{array}{l}\text { Teixeira } \\
\text { RN. } \\
2016 \\
{[65]}\end{array}$ & $\begin{array}{l}\text { Woolf } \\
\text { S. } \\
2002 \\
{[63]}\end{array}$ & $\begin{array}{l}\text { Besomi } \\
\text { M. } \\
2019 \\
{[66]}\end{array}$ \\
\hline $\begin{array}{l}\text { Was the sample frame appropriate to address the target } \\
\text { population? }\end{array}$ & Yes & Yes & Yes & Unclear & Yes & Yes & Yes & Yes \\
\hline Were study participants sampled in an appropriate way? & Yes & No & Unclear & Yes & Yes & Unclear & Unclear & Yes \\
\hline Was the sample size adequate? & Yes & Yes & Yes & Unclear & Yes & Yes & Yes & Yes \\
\hline $\begin{array}{l}\text { Were the study subjects and the setting described in } \\
\text { detail? }\end{array}$ & Yes & Yes & Yes & Yes & Yes & Yes & Yes & Yes \\
\hline $\begin{array}{l}\text { Was the data analysis conducted with sufficient coverage } \\
\text { of the identified sample? }\end{array}$ & Yes & Yes & Yes & Yes & Yes & Yes & Yes & Yes \\
\hline $\begin{array}{l}\text { Were valid methods used for the identification of the } \\
\text { condition? }\end{array}$ & Yes & No & Yes & Yes & Yes & Yes & Unclear & Yes \\
\hline $\begin{array}{l}\text { Was the condition measured in a standard, reliable way } \\
\text { for all participants? }\end{array}$ & Yes & No & Yes & Yes & Yes & Yes & Yes & Yes \\
\hline Was there appropriate statistical analysis? & Yes & Yes & Yes & Yes & Yes & Yes & Yes & Yes \\
\hline $\begin{array}{l}\text { Was the response rate adequate, and if not, was the low } \\
\text { response rate managed appropriately? }\end{array}$ & Yes & Yes & Yes & Yes & Yes & Yes & Unclear & Yes \\
\hline
\end{tabular}


Table 7 Results about prevalence and incidence of LBP

\begin{tabular}{|c|c|c|c|c|c|c|c|c|c|}
\hline \multirow[t]{2}{*}{ Author, year } & \multirow[t]{2}{*}{ Study design } & \multicolumn{4}{|c|}{ Incidence } & \multicolumn{4}{|c|}{ Prevalence } \\
\hline & & Lifetime & 1 year & Point & Other & Lifetime & 1 year & Point & Other \\
\hline Bach DK, 1985 [72] & Prospective Cohort & & $22 \%$ & & & & & & \\
\hline Besomi M, 2019 [66] & Cross Sectional Survey & & & & & & $13.5 \%$ & $0.7 \%$ & \\
\hline Buist I, 2008 [73] & Prospective Cohort & & & & $4.8 \%$ (protocol event: 8 weeks) & & & & \\
\hline Chang WL, 2012 [67] & Cross Sectional Survey & & & & & $3.2 \%$ & & & \\
\hline Clement DB, 1981 [69] & Retrospective Survey & & & & $3.7 \%$ (2 years) & & & & \\
\hline Dallinga J, 2019 [80] & Prospective Cohort & & & & $1.9 \%$ (protocol event: 12 weeks) & & & & \\
\hline Ellapen TJ, 2013 [70] & Retrospective Descriptive & & & & & & $14 \%$ & & \\
\hline Kluitenberg B, 2015 [76] & Prospective Cohort & & & & $0.3 \%$ (protocol event: 6 weeks) & & & & \\
\hline Lysholm J, 1987 [74] & Prospective Cohort & & $5 \%$ & & & & & & \\
\hline Marti B, $1988[68]$ & Cross Sectional Survey & & & & & & $0.7 \%$ & & \\
\hline Malliaropoulos N, 2015 [64] & Cross Sectional & & & & & $20.2 \%$ & & & \\
\hline Messier SP, 2018 [79] & Prospective Cohort & & & & $6 \%$ (2 years) & & & & \\
\hline Rasmussen CH, 2013 [71] & Retrospective Cohort & & & $0.5 \%$ & & & & & \\
\hline Tauton JE, 2003 [75] & Prospective Cohort & & & & 1.6\% (protocol event: 13 weeks) & & & & \\
\hline Teixeira RN, 2016 [65] & Cross Sectional & & & & & & $14 \%$ & & \\
\hline Van der Worp MP, 2016 [77] & Prospective Cohort & & & & $2.7 \%$ (12 weeks) & & & & \\
\hline Von Rosen P, 2017 [78] & Prospective Cohort & & $2.8 \%$ & & & & & & \\
\hline Walter SD, 1989 [81] & Prospective Cohort & & & $1.8 \%$ & & & $4.3 \%$ & & \\
\hline Woolf SK, 2002 [63] & Cross Sectional Survey & & & & & & & $13.6 \%$ & \\
\hline
\end{tabular}

Walter et al. [81], the 1-year prevalence of LBP among 1288 runners was $4.3 \%$. The highest lifetime prevalence rate of LBP was reported to be $20.2 \%$ in the crosssectional study of Malliaropoulos et al. [64] in a sample of 40 ultra-trail runners. Furthermore, in another cross sectional study [67], the LBP lifetime prevalence was
$3.2 \%$ [67], in a sample of 893 subjects of which $80 \%$ of male runners [67].

\section{Incidence of LBP}

Twelve [69, 71-81] of the 19 included studies addressed incidence of LBP among runners. Ten were prospective

Table 8 Risk Factors for the onset LBP

\begin{tabular}{|c|c|c|c|}
\hline Author & Risk Factors For LBP & P-Value & Odds Ratio \\
\hline Clement DB, 1981 [69] & $\begin{array}{l}\text { - Leg-length discrepancy } \\
\text { - Reduced hamstrings flexibility } \\
\text { - Reduced back flexibility }\end{array}$ & $\begin{array}{l}1 \\
1 \\
1\end{array}$ & \\
\hline Ellapen TJ, 2013 [70] & - Hip flexion angles (female) -(Thomas Test + goniometer) & $p<0.01$ & $\dagger 3.0488$ \\
\hline $\begin{array}{l}\text { Malliaropoulos N, } 2015 \\
\text { [64] }\end{array}$ & - $>$ than 6 years of experience in running & $\begin{array}{l}P= \\
0.012\end{array}$ & $\dagger 5.4857$ \\
\hline Woolf SK, 2002 [63] & $\begin{array}{l}\text { - Not equal wear of heels } \\
\text { - BMl } \geq 24^{1} \\
\text { - Not performing Weekly aerobics activity } \\
\text { - Not Play in contact sports regularly }{ }^{1} \text { (i.e. football, soccer, basketball, wrestling, boxing, } \\
\text { rugby } \\
\text { - Not using orthotics + not equal wear of heels } \\
\text { - Outside pattern of wear } \\
\text { - Running without Inside pattern of wear }{ }^{2} \\
\text { - Higher Physical height; } \\
\text { - Flexibility exercises routine for a longer time before working out }{ }^{2} \\
\text { - Not doing Traditional aerobics activity }{ }^{2}\end{array}$ & $\begin{array}{l}p= \\
0.034 \\
p<0.01 \\
p<0.05 \\
p<0.04 \\
p= \\
0.011 \\
p= \\
0.013 \\
p \leq 0.02 \\
p \leq 0.02 \\
p \leq 0.05 \\
p<0.05\end{array}$ & $\begin{array}{l}\neq 1.263 \text { (female } \\
\wedge \mathrm{BMI}) \\
\neq 1.122(\text { male } \wedge \text { BMI) }\end{array}$ \\
\hline
\end{tabular}

* higher credits as a sum of sex and age of the runner, difficulty level of previous races - positive height difference, the vertical climb index, and the distance in km - and performance.1 Previous LBP; a Subgroup of runners without insert; 2 Current LBP; †value calculated by authors using data from the full-text; $\neq$ value reported directly from the full-text 
studies [72-81], and two were a retrospective study [69, 71]. Overall, the incidence of LBP among runners ranged from a minimum of $0.35 \%$ (in 6 weeks) [76] and maximum value of $22 \%$ (in 1-year) [72]. The highest incidence rate of LBP was reported as equal to $22 \%$ (7 male; 3 female) in the prospective study of Bach et al. [72] in a sample of 45 runners.

The minimal rate of incidence, below $1 \%$, was found in the studies by Kluitenberg et al. [76] and Rasmussen et al. [69] with values of 0.35 and $0.5 \%$, respectively.

Furthermore, overall low incidence values, beneath 5\%, were found in other six studies $[69,73,75,77,78,80$, 81]. Among them, a value of $1.6 \%$ (in 13 weeks) was found in the prospective study of Tauton et al. [73] for the distribution of injuries in the lower back. A similar value $(1.8 \%)$ was found in Walter et al. [81]. In a more recent prospective cohort study of Dallinga et al. [80] an incidence rate of $1.9 \%$ (in 12 weeks) was found in a sample of recreational runners, during the training period for a running event. More in depth, the analysis of Van Der Worp et al. [77] showed a rate of $2.7 \%$ (in 12 weeks) in a sample of adult women runners. Moreover, the prospective cohort study of Von Rosen et al. [78] reported the incidence of injuries in the lower back of $2.8 \%$ of all injuries recorded between young female runners (mean age 17 years). Lastly, in the study of Buist et al. [73], a value of $4.8 \%$ (in 8 weeks) was found among a sample of novice runners, in runners with previous experience who have started running again and runners engaged in regular running [73]..

In the remaining two prospective cohort studies [74, 79], the incidence rate of LBP was found to be slightly higher. Indeed, Lysholm et al. [74] reported a 1-years incidence equal to $5 \%$ among a small sample of 39 runners and in the recent study of Messier et al. [79] the incidence (in 2 years) of LBP among runners was $6 \%$, considering the anatomical sites of back and pelvis. In the end, the retrospective analysis of Clement et al. [69] among 1650 runners revealed similar findings: the 2 years-incidence of injuries localized in the lower back was $3.7 \%$ (3.3\% for men and $4.3 \%$ for women).

\section{Risk factors for LBP}

The risk factors for the onset of LBP are reported in Table 8. Four studies [63, 64, 69, 70] addressed specific risk factors for LBP in runners. Two of them were retrospective studies $[69,70]$ and two were cross sectional studies $[63,64]$. The retrospective analysis of Clement et al. [69] indicated as possible risk factors for the development of non-specific back pain in runners leg-length discrepancy, poor hamstrings flexibility and poor back flexibility [69]. However, the authors did not specify the strength of the associations with LBP and the values of statistical significance. In another retrospective study
[70] on recreational runners' tightness of hip flexors and hip flexion angle measured both with the Thomas test (a clinical and physical test used to measure the flexibility of the hip flexors, which includes the iliopsoas muscle group, the rectus femoris, pectineus, gracillis as well as the tensor fascia latae and the sartorius [82] and goniometer were defined as potential intrinsic factors predisposing to lower back/hip injuries. Indeed, the hip flexion angles of female runners who have suffered lower back/ hip musculoskeletal injuries were significantly greater, than those of their not-injured counterparts $(p<0.01)$ [70]. Risk factors are listed in Table 8.

Moreover, the cross-sectional study of Malliaropoulos et al. [64] highlighted that having more than 6 years of experience of running could represent a predicting factor for getting injured in the lower back $(p=0.012)$ [64].

Lastly, Woolf et al. [63], in a cross sectional study conducted on a wide sample of runners, showed that runners who have previously suffered LBP, have reported greater shoe wear on either the inside or outside. Conversely, an equal shoe wear was less likely to relate a previous history of LBP $(p=0.034)$ [63].

In the same study [63], a previous history of LBP was reported by runners who did not use orthotics (such as insert, insole, heel, foot-bed, etc.) $(p=0.011)$, by who had a body mass index higher than $24(\mathrm{p}<0.01)$ and by who did not perform weekly traditional aerobics activity $(p<0.05)$.

Moreover, again in the study of Woolf et al. [63], runners who did not regularly play contact sports (e.g., football, soccer, basketball, wrestling, boxing, rugby) were more likely $(p<0.04)$ to have suffered LBP than those who do [63]. Current LBP was reported by high stature $(\mathrm{p}<=0.02)$ runners and by who perform a long time flexibility exercises routine before the training $(\mathrm{p}<=$ $0.05)$ [63].

\section{Discussion}

The aim of this SR was to investigate the prevalence and incidence of LBP and to identify risk factors for the onset of LBP among runners. To the best of the authors' knowledge, this is the first SR addressing these outcomes in this specific population.

\section{Prevalence and incidence of LBP}

Despite running is one of the most practiced sports worldwide, and the prevalence rate of RRI is well documented in scientific literature [1-11], prevalence and incidence of LBP among runners are still unclear. The relatively low number of studies that we were able to include in the present review confirms the scarcity of literature on this topic.

Overall, the findings of this SR revealed that LBP prevalence and incidence among runners, compared to 
the general population [35-40], were low. In detail, according to the results, within the most represented sports population among the analyzed studies (i.e. 2050 years of age), running does not appear to be related to higher rates of incidence and prevalence of LBP, if compared to the general population presenting same age $[40,83,84]$.

Indeed, within the general population, the point prevalence estimate of LBP was described in a range of $1-58 \%$ (mean 18.1\%) [39, 40], while in our review the point prevalence was $0.7-13.6 \%$, however retrievable only in two studies. The one-year and lifetime prevalence of LBP, calculated in the worldwide population, ranged between 0.8 and $82.5 \%$ (mean $38.1 \%$ ) and $11-84 \%$ (mean $47.2 \%)$, respectively $[39,40]$. Conversely, in our review, the one-year and lifetime prevalence ranged between 0.7 and $14 \%[65,66,68,70,81]$ and $3.2 \%$ [67] and $20.2 \%$ [64], respectively. The same considerations may be made for the incidence, indeed the one-year incidence in the general population was 36\% [39], while data emerging from our SR indicate that 1-year incidence reported a range from $2.8 \%$ [78] to $22 \%$ [72].

Moreover, it should be noted that the results of two studies reporting high prevalence (20.2\% lifetime) [64], and high incidence (22\% 1-year) [72], is probably depending from the very small $[64,72]$ and the specific sample of 40 ultra-trail runners (that face with races taking place on mountain, desert, or forest and it includes uphill, downhill and is similar in duration to an ultramarathon, that is beyond the distance of a regular marathon of $42.195 \mathrm{~km}$ ) [64].

Regarding the mileage, it is worth pointing out that LBP prevalence in runners seems to be somehow independent of the running distance. In Besomi et al. [66] the largest sample (4380) within studies included in our SR, prevalence was assessed on a race of three difference distances $(10,21$ and $42 \mathrm{~km})$. The rate of prevalence in the $42 \mathrm{~km}$-runners was similar $(7.5 \%)$ to the rate among the $21 \mathrm{~km}$-runners, $(7.5 \%)$.

Moreover, the findings of this SR revealed that the LBP prevalence and incidence in runners seem to be less relevant compared with the benchmarks of RRI in literature $[2,10,11,16-20,61,62,79-81,85,86]$. Indeed, the RRIs affecting lower limbs seem to have much greater prevalence rates, reporting a range of value of $28-42 \%$ for the knee (e.g., patellar tendinopathy, iliotibial band syndrome, patellofemoral pain syndrome), and of $14-38 \%$ for the ankle (e.g., ankle sprain, Achilles tendinopathy, plantar fasciopathy) [16-20, 61, 62, 79-81, 85-87].

Although prevalence and incidence of LBP appear low if compared to the general population, this conclusion should be taken cautiously. Indeed, out of the scarcity of the available studies, there are many points in the included studies that weaken the generalizability of this statement.

Further studies are needed in order to extend the results of this systematic review to the older adult population, because LBP incidence and prevalence values increase with age [83, 84].

Transversely to all the included studies, participants were heterogeneous for individual characteristics (age, sex), training level and previous injuries. Therefore, it is reasonable that various samples of populations (ex. young elite athletes or middle-aged recreational runners) may led to different prevalence or incidence rates. Furthermore, as reported in some prospective studies, not all the participants were exposed to the same running or training methods. In the cross-sectional survey study of Woolf et al. [63] for example, the rate of LBP pointprevalence, was calculated not only within experienced runners, but also between novice runners. Instead, in the study of Marti et al. [64] the 1-year prevalence of LBP, $0.7 \%$, was estimated in a wide sample, 4358 runners, but constituted of only male runners; In the cross-sectional study of Teixeira et al. [65] which is the only one to report the International Association for the Study of Pain (IASP) definition of pain [86], the prevalence of LBP was calculated among elite marathon runners who compete at international and/or national level and perform high volume of training, up to $160 \mathrm{~km} /$ week. In the crosssectional study of Chang et al. [67] in a sample of 893 runners (mostly composed of male) although the lifetime prevalence rate was low, $3.2 \%$, runners were not specifically asked if they had the symptom at the time of completing the questionnaire. Concerning the incidence, in the prospective study of Bach et al. [72] the highest rate of LBP (22\%; 7 males, 3 females) was found within a small sample of 45 runners. In the two prospective cohort studies [77, 78], the rate of incidence was assessed in samples made up exclusively of female runners and four studies evaluated incidence rates of LBP in only novice runners [75-77, 79]. Clement et al. [69] was the only study that used the term "Non-specific lower back pain", as reported by the most recent literature $[57,88]$ and only seven among the included studies $[63,64,66$, $69,72,74,78]$, to define an injury affecting the lumbar spine, adopted specific terms such as low/lower back pain, LBP, Non-specific lower back pain.

\section{Risk factors}

Only four studies addressed specific risk factors for the onset of LBP among runners $[63,64,69,70]$ and great caution is required for translating their results to general practice being those studies two retrospective studies $[69,70]$ and the two cross-sectional studies [63, 64], which do not represent the most reliable study design to assess risk factors. 
According to the Comprehensive Model for Injury Causation [60] and the Conceptual Model for the Determinants of RRIs [89], intrinsic and extrinsic factors are responsible for the increase of running injury risk. Intrinsic factors are hardly or not modifiable; they include sex $[60,89]$, age $[60,89]$, BMI $[60,89]$, history of previous injury [60, 89], physical fitness and psychological factor have been found to predispose runners to injury $[60,89]$. Otherwise, extrinsic factors are modifiable, and comprise training volume or other characteristics, as sport equipment and training environment, which rise the runner's susceptibility to injury $[60,89]$. Intrinsic risk factors proposed for the onset of LBP among runners included: BMI $\geq 24$ [63]; higher physical height [63]; tightness of hip flexors (measured by Thomas Test) [70] and hip flexion angles (only in female and measured by goniometer) [70]; but, as referred by the authors, there is no strong literature to explain this two last finding [70]. Moreover, the identification by Clement et al. [67] of physical impairments, like reduced hamstring or back flexibility and leg length discrepancy, was not supported by statistical evaluation. Notably, if the runners are compared to non-runners, these seem to present a significantly lower degree of hip flexion with the knee extended, indicating a tightness of hamstrings $(p<$ 0.001). Nonetheless, no correlation was found between muscular tightness in runners and the incidence of LBP [72]. Due to the scarcity of available studies and the clinical impression that muscles tightness could be a risk factor for RRIs and LBP, this topic should be investigated in large samples using prospective design.

The main extrinsic risk factors for the onset of LBP among runners were: high competitive level [64]; more than 6 years of experience in running [64]; some patterns of shoes' wear [63] and do not performing weekly aerobics activity [63].

Also in this case the findings extracted from the two selected studies $[63,64]$ cannot be directly translated to the daily practice, but could only serve as possible additional elements to support the clinician in the interpretation of the athlete's condition. Indeed, the exposure to a single risk factor is often insufficient to produce an overuse injury: the RRI is the result of a number of superposing factors (like training increase, muscular impairments, unsuitable equipment, etc.) [66].

\section{Consistency}

There is a need of a standard and internationally acceptable definitions for LBP and a clearer definition and terminology of RRI. RRI is defined as an overuse injury due to an unbalance between the resistance capacity of connective tissue and the biomechanical solicitations of running $[14,15]$. Therefore, here the meaning of "injury" differs from usual meaning which is related to an acute trauma and, in a clinical perspective, very rare among runners $[3,14,15]$.

In our view, a more suitable word may be "Disorder" (Running Related Disorders - RRDs) that better describes multifactorial conditions which include, beside structural aspect, also psychosocial elements often present in nonspecific painful disorders like LBP [90-93].

Our SR confirmed, also for running, the findings of a recent SR [33] which concluded that the evidence about prevalence of LBP in athletes of some popular sports are scarce and derived from studies not of good methodological quality. This SR showed a quite high LBP prevalence among athletes, but this finding was relative to a wider sample of sports including volleyball, track and fields, swimming, golf, ski, gymnastics and rowing [33, 43-48], not specifically including running.

\section{Clinical implications}

Despite a significant correlation between spinal shrinkage, running speed and distance covered exists, it is not correlated to the onset or presence of LBP [94]. Moreover, some studies suggested that running could have an anabolic role towards the intervertebral disc [95-98], among them Belavý et al. [97] reported that longdistance runners and joggers showed better hydration and glycosaminoglycan levels than the non-athletic individuals.

These findings, together with the low level of incidence and prevalence of LBP among runners, cautiously invite thinking running as a protective factor from LBP and to consider of prescribing running as a preventive exercise for LBP.

Although the data available on risk factors are weak and not conclusive, nevertheless most of proposed running related risk factors were modifiable by specific intervention and adapted training and they should be taken into consideration by physical therapists and trainers.

\section{Implications for research}

More high-quality studies that analyse the prevalence and incidence of LBP in runners are needed before drawing strong and definitive conclusions. The actual prevalence and incidence of LBP in runners should be investigated by large cohort studies, adopting better definition of the clinical symptoms, rather than just pain distribution in anatomical districts. Moreover, a consensus on the definition of RRIs that consider the inclusion of psychosocial aspect and widens the usual pathoanatomic approach is advisable due the characteristics of conditions like LBP.

Risk factors should be assessed by methodologically sound prospective studies on more homogeneous populations (in terms of demographic characteristics, training 
level of participants, gender, age, etc.). As reported by our results, running seems to represent a sport without an increased rate of LBP: data of LBP prevalence and incidence among runners are lower than those found in other sports [33, 41]. However, caution is required when assuming that run could be a good practice in order to prevent LBP. Our findings mostly derive from novice runners or recreational runners, so it would be pretentious to apply in other sports and in elite/professional contexts.

\section{Perspective}

Running is one of the most practiced sports [1-11] and although evidence suggests that is one of the most effective ways to achieve a good state of health [9], recent studies indicate that it also involves a relatively high risk of injuries $[10,11]$. Currently a definition of RRIs is not yet fully share, this is reflected in the difficulty of analyzing the studies about of RRIs [18]. RRIs primarily affect joints of the lower limb and lumbar spine $[18,25,26$, 99], causing painful muscles, tendons and joints, also resulting in LBP [14-26], but despite several studies about the prevalence and incidence of LBP in sports are retrievable [35-40], it seems that this topic has not been clearly investigated in the runners. Therefore, the aetiology, the prevalence and the incidence of LBP, likewise the RRI, have been reviewed. Specifically, it is important to consider how often the effectiveness of a given RRI prevention intervention is dependent on an easy modification of etiologic factors, and on and their consistency with a biologically plausible causal mechanism [24]. Therefore, the investigation of how different factors affect the lumbar spine, in terms of structure-specific load and/or loadability, and the dose-response relationship between running participation and injury risk [24]. These considerations allow researchers to move beyond traditional risk factor identification. Just so, research findings could be reliable, not only in terms of the observed cause-effect association but also translatable in clinical practice [24].

Moreover, although the encouraging results, they are limited to the population most represented among the studies analysed (20-50 years of age), from this perspective, running activity could be used as a strategy to maintain a healthy lifestyle in the adult population, as indicated by the World Health Organization guidelines (WHO) [100].

\section{Limitations}

This SR has several limits. Studies written in languages other than English or Italian were excluded and, due to the heterogeneity of the included studies were not possible to perform a meta-analysis.
We have not included sprinter runners in the research strategies, as keyword. Moreover, we have adopted a strict topographical definition of LBP [56], while in other epidemiological studies the authors referred as a LBP a generic "back pain", which could involve even the thoracic region [34, 40, 83, 84, 101]. Moreover, a homogeneous definition of LBP was not adopted in all studies, populations investigated were different and prevalence, incidence or risk factors for the onset of LBP are investigated by questionnaires that are exposed to recall bias.

Furthermore there is a high risk of selection bias in the studies, in that persons with LBP may not be able to run, increasing the rate of prevalence of LBP in general population.

Lastly, being unavailable a specific and validated assessment tool for retrospective studies, for the assessment of the methodological quality of the included studies was adopted the tool designed for case-control studies.

Finally, it would be also necessary to tighten up the definitions of both incidence and prevalence rates [53], which are sometimes confused or inverted, and therefore create difficulties in the interpretation of data.

\section{Conclusion}

Despite the small number of included studies, the heterogeneity of the samples investigated and of running modalities did not allow to gain conclusive results, the prevalence and incidence of LBP among runners appear to be low if compared to the general population and to other RRIs. Most of the physical and training-related risk factors for the onset of LBP, even based on weak evidence, are potentially modifiable by a careful intervention of the clinician and should be considered when LBP prevention is sought.

\section{Supplementary information}

Supplementary information accompanies this paper at https://doi.org/10. 1186/s12891-020-03357-4.

\section{Additional file 1. Database search Strategy}

\section{Abbreviations}

LBP: Low Back Pain; SR: Systematic Review; RoB: Risk of Bias; RRls: Running Related Injuries; RRDs: Running Related Disorders; PROSPERO: Prospective Register of Systematic Reviews; WHO: World Health Organization

\section{Acknowledgements}

Not applicable.

\section{Authors' contributions}

Analyzed the data: FM, AC. Contributed materials/analysis tools: FM, AC; LS, VB. Wrote the article: FM, LS, VB, MT. Substantial contributions to conception and design, acquisition of data: FM, AC, LS, VB. Analysis and interpretation of data: FM, LS, VB, MT. Drafting the article or revising it critically for important intellectual content: FM, GR, SG, AT, MT. Final approval of the version to be published: FM, LS, VB, AC, GR, SG, AT; MT. All authors have read and approved the manuscript. 


\section{Funding}

This research received no external funding.

\section{Availability of data and materials}

All data generated or analyzed during this study are included in this published study. Other information of this study are available from the corresponding author on reasonable request.

\section{Ethics approval and consent to participate}

Not applicable.

\section{Consent for publication}

Not applicable.

\section{Competing interests}

The authors declare that they have no competing interests.

\section{Author details}

'Department of Neurosciences, Rehabilitation, Ophthalmology, Genetic and Maternal Infantile Sciences (DINOGMI), University of Genova - Campus of Savona, Savona, Italy. ${ }^{2}$ Sovrintendenza Sanitaria Regionale Puglia INAIL, Bari, Italy. ${ }^{3}$ RCCS, San Camillo, Laboratory of Rehabilitation Technologies, Rehabilitation Research Unit, Venice, Italy. ${ }^{4}$ IRCCS, Istituto Ortopedico Galeazzi, Unit of Clinical Epidemiology, Milano, Italy.

\section{Received: 19 December 2019 Accepted: 20 May 2020}

\section{Published online: 03 June 2020}

\section{References}

1. van Gent RN, Siem D, van Middelkoop M, van Os AG, Bierma-Zeinstra SMA, Koes BW. Incidence and determinants of lower extremity running injuries in long distance runners: a systematic review. Br J Sports Med. 2007;41(8):46980.

2. van Middelkoop M, Kolkman J, Van Ochten J, Bierma-Zeinstra SMA, Koes B. Prevalence and incidence of lower extremity injuries in male marathon runners. Scand J Med Sci Sports. 2008;18:140-4.

3. Maselli F, Viceconti A, Rossettini G, Testa M. Importance of screening in physical therapy: vertebral fracture of thoracolumbar junction in a recreational runner. BMJ Case Rep. 2019;12:e229987.

4. Maselli F, Testa M. Superficial peroneal nerve schwannoma presenting as lumbar radicular syndrome in a non-competitive runner. J Back Musculoskelet Rehabil. 2019;32(2):361-5.

5. Franke TPC, Backx FJG, Huisstede BMA. Running themselves into the ground? Incidence, prevalence, and impact of injury and illness in runners preparing for a half or full Marathon. J Orthop Sports Phys Ther. 2019;49(7): $518-28$

6. Oja P, Titze S, Kokko S, Kujala UM, Heinonen A, Kelly P, Koski P, Foster C. Health benefits of different sport disciplines for adults: systematic review of observational and intervention studies with meta-analysis. Br J Sports Med. 2015:49:434-40.

7. Hulteen RM, Smith JJ, Morgan PJ, Barnett LM, Hallal PC, Colyvas K, Lubans DR. Global participation in sport and leisure-time physical activities: a systematic review and metaanalysis. Prev Med. 2017:95:14-25.

8. van Dyck D, Cardon G, de Bourdeaudhuij I, de Ridder L, Willem A. Who participates in running events? Socio-demographic characteristics, psychosocial factors and barriers as correlates of non participation - a pilot study in Belgium. Int J Environ Res Public Health. 2017;14:E1315.

9. Fields KB, Sykes JC, Walker KM, et al. Prevention of running injuries. Curr Sports Med Rep. 2010:9:176.

10. Nielsen RO, Buist I, Sorensen H, Lind M, Rasmussen S. Training errors and running related injuries: a systematic review. Int J Sports Phys Ther. 2012;7:58

11. van der Worp MP, ten Haaf DSM, van Cingel R, de Wijer A, Nijhuis-van der Sanden MWG, Staal JB. Injuries in Runners; A Systematic Review on Risk Factors and Sex Differences. PLoS One 2015; 10(2):e0114937.

12. Kemler E, Blokland D, Backx F, Huisstede B. Differences in injury risk and characteristics of injuries between novice and experienced runners over a 4 year period. Phys Sportsmed. 2018;46(4):485-91.

13. Van Mechelen W. Running injuries: a review of the epidemiologic literature. Sports Med. 1992;14(5):320-35.

14. Walther M, Reuter I, Leonhard T, Engelhardt M. Verletzungen und überlastungsreaktionen im laufsport. Orthopäde. 2005;34:3999.
15. Hreljac A, Marshall RN, Hume PA. Evaluation of lower extremity overuse injury potential in runners. Med Sci Sports Exerc. 2000;32(9):1635-41.

16. Van Der Worp MP, De Wijer A, Van Cingel R, Verbeek ALM. Nijhuis-Van Der Sanden MWG, Staal JB. The 5- or 10-km Marikenloop run: a prospective study of the etiology of running-related injuries in women. J Orthop Sports Phys Ther. 2016;46(6):462-70.

17. Hreljac A. Etiology, prevention, and early intervention of overuse injuries in runners: a biomechanical perspective. Phys Med Rehabil Clin N Am. 2005;16: 651-67.

18. Lopes AD, Hespanhol Júnior LC, Yeung SS, Costa LO. What are the main running-related musculoskeletal injuries? A systematic review. Sports Med. 2012:42:891-905.

19. Taunton JE, Ryan MB, Clement DB, McKenzie DC, Lloyd-Smith DR, Zumbo $\mathrm{BD}$. A retrospective case control analysis of 2002 running injuries. $\mathrm{Br} J$ Sports Med. 2002:36:95-101.

20. Yamato TP, Saragiotto BT, Lopes AD. A consensus definition of runningrelated injury in recreational runners: a modified Delphi approach. J Orthop Sports Phys Ther. 2015;45(5):375-80.

21. Hoeberigs $\mathrm{JH}$. Factors related to the incidence of running injuries. Review Sports Med. 1992;13:408-22.

22. Satterthwaite $P$, Norton $R$, Larmer $P$, Robinson E. Risk factors for injuries and other health problems sustained in a marathon. Br J Sports Med. 1999;33: 22-6.

23. Borel WP, Filho JE, Mata Diz JB, Moreira PF, Veras PM, Catharino LL, Bárbara Palmeira Rossi BP, Diogo Carvalho Felício DC. Prevalence of injuries in Brazilian recreational street runners: meta-analysis. Rev Bras Med Esporte 2019; 25(2):161-167.

24. Bertelsen ML, Hulme A, Petersen J, Brund RK, Sørensen H, Finch CF, Parner ET, Nielsen RO. A framework for the etiology of running-related injuries. Scand J Med Sci Sports. 2017:27(11):1170-80.

25. Hreljac A. Impact and overuse injuries in runners. Med Sci Sports Exerc. 2004:36:845-9.

26. Pinshaw R, Atlas V, Noakes TD. The nature and response to therapy of 196 consecutive injuries seen at a runners' clinic. S Afr Med J. 1984;65(8):291-8.

27. Henschke N, Maher CG, Refshauge KM. Screening for malignancy in low back pain patients: a systematic review. Eur Spine J. 2007:16:1673-9.

28. Henschke N, Maher CG, Refshauge KM, Herbert RD, Cumming RG, Bleasel J, York J, Das A, McAuley JH. Prevalence of and screening for serious spinal pathology in patients presenting to primary care settings with acute low Back pain. Arthritis Rheumatism. 2009;60(10):3072-80.

29. Williams CM, Henschke N, Maher CG, van Tulder MW, Koes BW, Macaskill P, Irwig $L$. Red flags to screen for vertebral fracture in patients presenting with low-back pain. Cochrane Database Syst Rev. 2013;1:CD008643.

30. Premkumar A, Godfrey W, Gottschalk MB, Boden SD. Red flags for low Back pain are not always really red: a prospective evaluation of the clinical utility of commonly used screening questions for low Back pain. J Bone Joint Surg Am. 2018;100(5):368-74.

31. Piano L, Maselli F, Viceconti A, Gianola S, Ciuro A. Direct access to Physcial therapy for patient with musculoskeletal disorders, a literature review. J Physical Therapy. 2017;29(8):1463-71.

32. Fett $\mathrm{D}$, Trompeter $\mathrm{K}$, Platen $\mathrm{P}$. Prevalence of back pain in a group of elite athletes exposed to repetitive overhead activity. PLoS One. 2019;14(1): e0210429.

33. Farahbakhsh F, Rostami M, Noormohammadpour P, Mehraki Zade A, Hassanmirazaei B, Faghih Jouibari M, Kordi R, Kennedy DJ. Prevalence of low back pain among athletes: a systematic review. J Back Musculoskelet Rehabil. 2018:31(5):901-16.

34. Fatoye F, Gebrye T, Odeyemi I. Real-world incidence and prevalence of low back pain using routinely collected data. Rheumatol Int. 2019;39(4):619-26.

35. Oliveira CB, Maher CG, Pinto RZ, Traeger AC, Lin CC, Chenot JF, van Tulder $M$, Koes BW. Clinical practice guidelines for the management of non-specific low back pain in primary care: an updated overview. Eur Spine J. 2018; 27(11):2791-803

36. Rubin Dl. Epidemiology and risk factors for spine pain. Neurol Clin. 2007; 25(2):353-71.

37. Hoy D, Brooks P, Woolf A, Blyth F, March L, Bain C, Buchbinder R. Assessing risk of bias in prevalence studies: modification of an existing tool and evidence of interrater agreement. J Clin Epidemiol. 2012;65(9): 934-9.

38. Valat JP, Goupille $P$, Védere V. Low back pain: risk factors for chronicity. Revue du rhumatisme (English ed.). 1997;64(3):189-94. 
39. Walker BF. The prevalence of low back pain: a systematic review of the literature from 1966 to 1998. Clin Spine Surg. 2000;13(3):205-17.

40. Hoy D, Brooks P, Blyth F, Buchbinder R. The epidemiology of low back pain. Best Pract Res Clin Rheumatol. 2010;24(6):769-81.

41. Trompeter K, Fett D, Platen P. Prevalence of Back pain in sports: a systematic review of the literature. Sports Med. 2017;47(6):1183-207.

42. Moradi V, Memari AH, ShayestehFar M, Kordi R. Low Back pain in athletes is associated with general and sport specific risk factors: a comprehensive review of longitudinal studies. Rehabil Res Pract. 2015;2015:850184.

43. d'Hemecourt PA. Gerbino 2nd PG, Micheli L. Back injuries in the young athlete. Clin Sports Med. 2000;19(4):663-79.

44. Trainor TJ, Wiesel SW. Epidemiology of back pain in the athlete. Clin Sports Med. 2002;21(1):93-103.

45. Ng L, Perich D, Burnett A, Campbell A, O'Sullivan P. Self-reported prevalence, pain intensity and risk factors of low back pain in adolescent rowers. J Sci Med Sport. 2014;17:266-70

46. Cole MH, Grimshaw PN. The biomechanics of the modern golf swing: implications for lower back injuries. Sports Med. 2016;46:339-51.

47. Smith JA, Hawkins A, Grant-Beuttler M, Beuttler R, Lee SP. Risk factor associated with low Back pain in golfers: a systematic review and metaanalysis. Sports Health. 2018;10(6):538-46.

48. Maselli F, Ciuro A, Mastrosimone R, Cannone M, Nicoli P, Signori A, Testa M. Low back pain among Italian rowers: a cross-sectional survey. J Back Musculoskelet Rehabil. 2015;28(2):365-76.

49. Graw BP, Wiesel SW. Low back pain in the aging athlete. Sports Med Arthrosc Rev. 2008;16(1):39-46.

50. Schmidt CP, Zwingenberger S, Walther A, Reuter U, Kasten P, Seifert J, Günther KP, Stiehler M. Prevalence of low back pain in adolescent athletes an epidemiological investigation. Int J Sports Med. 2014;35(8):684-9.

51. Purcell L, Micheli L. Low back pain in young athletes. Sports Health. 2009; 1(3):212-22.

52. Fett $D$, Trompeter $K$, Platen $P$. Back pain in elite sports: a cross-sectional study on 1114 athletes. PLoS One. 2017;12(6):e0180130.

53. Bhopal RS. Concepts of epidemiology: integrating the ideas, theories, principles, and methods of epidemiology. Oxford: Oxford University Press; 2016.

54. Hoskins W. Low Back Pain and Injury in Athletes in "Low Back Pain Pathogenesis and Treatment". Chapter 3, 41-68. In: Yoshihito S (Editors). In Tech; available from: http://www.intechopen.com/books/low-back-painpathogenesis-and-treatment/low-back-pain-and-injury-in-athletes.

55. Liberati A, Altman DG, Tetzlaff J, Mulrow C, Gøtzsche PC, loannidis JP, Clarke M, Devereaux PJ, Kleijnen J, Moher D. The PRISMA statement for reporting systematic reviews and meta-analyses of studies that evaluate health care interventions: explanation and elaboration. J Clin Epidemiol. 2009;62(10):e1-34.

56. Burton AK, Balagué F, Cardon G, Eriksen HR, Henrotin $Y$, Lahad A, Leclerc A, Müller G, van der Beek AJ, COST B13 Working Group on Guidelines for Prevention in Low Back Pain. Chapter 2. European guidelines for prevention in low back pain: November 2004. Eur Spine J. 2006;15(Suppl 2):S136-68.

57. Maher C, Underwood M, Buchbinder R. Non-specific low back pain. Lancet. 2017;389(10070):736-47.

58. Moola S, Munn Z, Tufanaru C, Aromataris E, Sears K, Sfetcu R, Currie M, Qureshi R, Mattis P, Lisy K, Mu P-F. Chapter 7: Systematic reviews of etiology and risk. In: Aromataris E, Munn Z (Editors). Joanna Briggs Institute Reviewer's Manual. The Joanna Briggs Institute, 2017. Available from https:// reviewersmanual.joannabriggs.org.

59. Altman DG. Practical statistics for medical research. 1st ed. London: Chapman and Hall; 1991

60. Bahr R, Krosshaug T. Understanding injury mechanisms: a key component of preventing injuries in sport. Br J Sports Med. 2005;39(6):324-9.

61. Nielsen RO, Nohr EA, Rasmussen S, Sørensen H. Classifying running-related injuries based upon etiology, with emphasis on volume and pace. Int J Sports Phys Ther. 2013;8(2):172-9

62. Scheer BV, Murray A. Al Andalus. Ultra Trail: an observation of medical interventions during a 219-km, 5-day ultramarathon stage race. Clin J Sport Med. 2011;21(5):444-6

63. Woolf SK, Barfield WR, Nietert PJ, Mainous AG 3rd, Glaser JA. The Cooper River bridge run study of low back pain in runners and walkers. J South Orthop Assoc. 2002;11(3):136-43.

64. Malliaropoulos N, Mertyri D, Tsaklis P. Prevalence of injury in ultra trail running. Human Movement. 2015;16(2):52-9.
65. Teixeira RN, Lunardi A, Da Silva RA, Lopes AD, Carvalho CR. Prevalence of musculoskeletal pain in Marathon runners who compete at the elite level. Int J Sports Phys Ther. 2016;11(1):126-31.

66. Besomi M, Leppe J, Mauri-Stecca MV, Hooper TL, Sizer PS. Training volume and previous injury as associated factors for running-related injuries by race distance: a cross-sectional study. J Human Sport Exercise. 2019;14(3):549-59.

67. Chang WL, Shih YF, Wen-Chen WY. Running injuries and associated factors in participants of ING Taipei Marathon. Physical Therapy Sport. 2012;13:170-4.

68. Marti B, Vader JP, Minder CE, Abelin T. On the epidemiology of running injuries. The 1984 Bern grand-prix study. Am J Sports Med. 1988;16(3):285-94.

69. Clement DB, Taunton JE, Smart GW, McNicol KL. A survey of overuse running injuries. Phys Sportsmed. 1981;9(5):47-58.

70. Ellapen TJ, Satyendra S, Morris J, van Heerden HJ, Phil D. Common running musculoskeletal injuries among recreational half-marathon runners in KwaZulu-Natal. S Afr J SM. 2013:25(2):39-43.

71. Rasmussen $\mathrm{CH}$, Nielsen $\mathrm{RO}$, Juul MS, Rasmussen S. Running volume and risk of running related injuries among marathon runners. Int I Sports Phys Ther. 2013;8(2):111-20.

72. Bach DK, Green DS, Jensen GM, Savinar-Nogue E. A comparison of muscular tightness in runners and nonrunners and the relation of muscular tightness to low back pain in runners. J Orthop Sports Phys Ther. 1985;6(6):315-23.

73. Buist I, Bredeweg SW, Bessem B, van Mechelen W, Lemmink KA, Diercks RL. Incidence and risk factors of running-related injuries during preparation for a 4-mile recreational running event. Br J Sports Med. 2010;44(8):598-604.

74. Lysholm J, Wiklander J. Injuries in runners. Am J Sports Med. 1987;15(2):168-71.

75. Taunton JE, Ryan MB, Clement DB, McKenzie DC, Lloyd-Smith DR, Zumbo $B D$. A prospective study of running injuries: the Vancouver sun run "in training" clinics. Br J Sports Med. 2003;37(3):239-44.

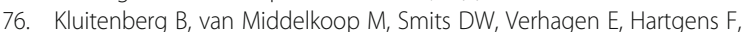
Diercks $\mathrm{R}$, van der Worp $\mathrm{H}$. The NLstart2run study: incidence and risk factors of running-related injuries in novice runners. Scand J Med Sci Sports. 2015; 25(5):e515-23.

77. van der Worp MP, de Wijer A, van Cingel R, Verbeek AL. Nijhuis-van der Sanden MW, Staal JB. The 5- or 10-km Marikenloop run: a prospective study of the etiology of running-related injuries in women. J Orthop Sports Phys Ther. 2016:46(6):462-70.

78. von Rosen P, Floström F, Frohm A, Heijne A. Injury patterns in adolescent elite endurance athletes participating in running, orienteering, and crosscountry skiing. Int J Sports Phys Ther. 2017;12(5):822-32.

79. Messier SP, Martin DF, Mihalko SL, Ip E, DeVita P, Cannon DW, Love M, Beringer D, Saldana S, Fellin RE, Seay JF. A 2-year prospective cohort study of overuse running injuries: the runners and injury longitudinal study (TRAILS). Am J Sports Med. 2018;46(9):2211-21.

80. Dallinga J, Van Rijn R, Stubbe J, Deutekom M. Injury incidence and risk factors: a cohort study of $7068-\mathrm{km}$ or $16-\mathrm{km}$ recreational runners. BMJ Open Sport Exerc Med. 2019;5(1):e000489.

81. Walter SD, Hart LE, McIntosh JM, Sutton JR. The Ontario cohort study of running-related injuries. Arch Intern Med. 1989;149(11):2561-4.

82. Harvey D. Assessment of the flexibility of elite athletes using the modified Thomas test. Br J Sports Med. 1998;32(1):68-70.

83. Meucci RD, Fassa AG, Faria NM. Prevalence of chronic low back pain: systematic review. Rev Saude Publica. 2015;49:S0034-89102015000100408.

84. Garcia JB, Hernandez-Castro JJ, Nunez RG, Pazos MA, Aguirre JO, Jreige A Delgado W, Serpentegui M, Berenguel M, Cantemir C. Prevalence of low back pain in Latin America: a systematic literature review. Pain Physician. 2014;17(5):379-91.

85. Easthope CS, Hausswirth C, Louis J, Lepers R, Vercruyssen F, Brisswalter J. Effects of a trail running competition on muscular performance and efficiency in well-trained young and master athletes. Eur J Appl Physiol. 2010;110(6):1107-16.

86. Merskey H, Albe-Fessard DG, Bonica JJ, Carmon A, Dubner R, Kerr FWL, Lindblom U, Mumford JM, Nathan PW, Noordenbos W, Pagni CA, Renaer MJ, Sternbach RA, Sunderland S. Pain terms: a list with definitions and notes on usage. Recommended by the IASP Subcommittee of taxonomy. Pain. 1979;6(3):249-52.

87. Arnold MJ, Moody AL. Common running injuries: evaluation and management. Am Fam Physician. 2018;97(8):510-6.

88. Aboagye E, Hagberg J, Axén I, Kwak L, Lohela-Karlsson M, Skillgate E, Dahlgren $G$, Jensen I. Individual preferences for physical exercise as secondary prevention for non-specific low back pain: a discrete choice experiment. PLoS One. 2017;12(12):e0187709. 
89. Malisoux L, Nielsen RO, Urhausen A, Theisen D. A step towards understanding the mechanisms of running-related injuries. J Sci Med Sport. 2015;18(5):523-8.

90. Lederman E. A process approach in manual and physical therapies: beyond the structural model. CPDO Online J. 2015; pp. 1-18. Available from: www. cpdo.net. Accessed 31 July 2019.

91. Nijs J, LluchGirbés E, Lundberg M, Malfliet A, Sterling M. Exercise therapy for chronic musculoskeletal pain: innovation by altering pain memories. Manual Ther. 2015;20:216-20.

92. Lluch Girbes E, Meeus M, Baert I, Nijs J. Balancing "hands on" with "handsoff" physical therapy interventions for the treatment of central sensitization pain in osteoarthritis. Manual Ther. 2015;20:349-52.

93. Brindisino F, Giovannico G, Maselli F. Conservative management in a patient with massive rotator cuff tear and rheumatoid arthritis. J Back Musculoskelet Rehabil. 2020:33(2):329-37.

94. Garbutt G, Boocock MG, Reilly T, Troup JD. Running speed and spinal shrinkage in runners with and without low back pain. Med Sci Sports Exerc. 1990;22(6):769-72

95. Belavý DL, Albracht K, Bruggemann GP, Vergroesen PPA, van Die JH. Can exercise positively influence the intervertebral disc? Sports Med. 2016;46: 473-85.

96. Brisby H, Wei AQ, Molloy T, Chung SA, Murrell GA, Diwan AD. The effect of running exercise on intervertebral disc extracellular matrix production in a rat model. Spine. 2010:35:1429-36.

97. Belavý DL, Quittner MJ, Ridgers N, Ling Y, Connell D, Rantalainen T. Running exercise strengthens the intervertebral disc. Sci Rep. 2017;7:45975.

98. Murray CJL, Vos T, Lozano R, Naghavi M, Flaxman AD, Michaud C, et al. Disability-adjusted life years (DALYs) for 291 diseases and injuries in 21 regions, 1990-2010: a systematic analysis for the global burden of disease study 2010. Lancet Lond Engl. 2012;380:2197-223.

99. Kluitenberg B, van Middelkoop M, Diercks $\mathrm{R}$, van der Worp $\mathrm{H}$. What are the differences in injury proportions between different populations of runners? A systematic review and meta-analysis. Sports Med. 2015;45(8):1143-61.

100. World Health Organization Website https://www.who.int/ dietphysicalactivity/factsheet_recommendations/en/. Accessed 14 Apr 2020

101. Dionne CE, Dunn KM, Croft PR, Nachemson AL, Buchbinder R, Walker BF, et al. A consensus approach toward the standardization of back pain definitions for use in prevalence studies. Spine (Phila Pa 1976). 2008;33(1): 95-103.

\section{Publisher's Note}

Springer Nature remains neutral with regard to jurisdictional claims in published maps and institutional affiliations.

Ready to submit your research? Choose BMC and benefit from:

- fast, convenient online submission

- thorough peer review by experienced researchers in your field

- rapid publication on acceptance

- support for research data, including large and complex data types

- gold Open Access which fosters wider collaboration and increased citations

- maximum visibility for your research: over $100 \mathrm{M}$ website views per year

At $\mathrm{BMC}$, research is always in progress.

Learn more biomedcentral.com/submissions 